\title{
Metabolism, health and fillet nutritional quality in Atlantic salmon (Salmo salar) fed diets containing $n$-3-rich microalgae
}

\author{
Katerina Kousoulaki ${ }^{1}{ }^{*}$, Tone-Kari Knutsdatter $\varnothing_{\text {stbye }}{ }^{1}$, Aleksei Krasnov ${ }^{1}$, Jacob Seilø Torgersen ${ }^{1}$, \\ Turid Mørkøre ${ }^{1}$ and John Sweetman ${ }^{2}$ \\ ${ }^{1}$ Nofima AS, Department of Nutrition and Feed Technology, N-5141 Fyllingsdalen, Norway \\ ${ }^{2}$ Alltech Inc., Sarney, Dunboyne, County Meath, Republic of Ireland
}

Received 21 October 2014 - Final revision received 10 March 2015 - Accepted 22 April 2015)

Journal of Nutritional Science (2015), vol. 4, e24, page 1 of 13

doi:10.1017/jns.2015.14

Abstract

Microalgae, as primary producers of EPA and DHA, are among the most prominent alternative sources to fish oil for $n$ - 3 long-chain PUFA in animal and human nutrition. The present study aimed to assess technical, nutritional and fish health aspects of producing $n$-3-rich Atlantic salmon (Salmo salar) fish fillets by dietary supplementation of increasing levels of a DHA-producing Schizochytrium sp. and reduced or without use of supplemental fish oil. Atlantic salmon smolt were fed diets with graded levels of microalgae for 12 weeks, during which all fish showed high feed intake rates with postprandial plasma leptin levels inversely correlating with final mean fish body weights. Fish performance was optimal in all experimental treatments (thermal growth coefficient about 4.0 and feed conversion ratio $0 \cdot 8-0.9)$, protein digestibility was equal in all diets, whereas dietary lipid digestibility inversely correlated with the dietary levels of the SFA 16 : 0. Fillet quality was good and similar to the control in all treatments in terms of $n$-3 long-chain PUFA content, gaping, texture and liquid losses during thawing. Histological fluorescence staining and immunofluorescence analysis of salmon intestines (midgut: base of intestine and villi) revealed significant effects on slime, goblet cell production and inducible nitric oxide synthase (iNOS) activity with increasing levels of dietary Schizochytrium sp. supplementation. Microarray analysis did not reveal any signs of toxicity, stress, inflammation or any other negative effects from Schizochytrium sp. supplementation in diets for Atlantic salmon.

Key words: $n$-3 Long-chain PUFA: Farmed salmon fish fillet nutritional quality: Microalgae

A large body of literature associates the consumption of $n$ - 3 longchain PUFA ( $n$-3 LC-PUFA), in particular EPA and DHA, with multiple benefits to human health, related to reduction of CHD-associated risk factors and mortalities ${ }^{(1,2)}$, IHD mortality and stroke ${ }^{(3)}$. The suggested mechanisms responsible include the hypotensive ${ }^{(4)}$, hypotriacylglycerolaemic ${ }^{(5)}$, anti-arrhythmic ${ }^{(6)}$, anti-thrombotic $^{(7)}$, anti-atherogenic and anti-inflammatory $(8,9)$ properties of $n$-3 LC-PUFA. Besides CHD, fish and fish oils may act preventively against several other diseases such as rheumatoid arthritis ${ }^{(10)}$, depression ${ }^{(11)}$, cognitive decline ${ }^{(12)}$, neurological disorders, such as Alzheimer's disease ${ }^{(13)}$, and psoriasis $^{(14)}$. The main readily available food source of $n-3$ LC-PUFA is fish and seafood ${ }^{(15)}$ as well as commercially available $n$-3 LC-PUFA nutrition additives; however, health benefits are associated with the consumption of either one of them ${ }^{(16-20)}$. Food-grade fisheries providing fish oil and fishmeal may have already reached their limit of sustainability ${ }^{(21-27)}$; thus further growth in the world supply of fish, fish oil and crustaceans can only be supported based on increased aquaculture activity. Global fish oil production is

Abbreviations: 0_ScYE, $0 \mathrm{~g} / \mathrm{kg}$ Scizochytrium sp. + yeast extract (control); 1_ScYE, $10 \mathrm{~g} / \mathrm{kg}$ Scizochytrium sp. + yeast extract; 6_ScYE, 60 g/kg Scizochytrium sp. + yeast extract; 15_ScYE , $150 \mathrm{~g} / \mathrm{kg}$ Scizochytrium sp. + yeast extract; ADC, apparent digestibility coefficient; CK, creatine kinase; FAME, fatty acid methyl esters; FCR, feed conversion ratio; iNOS, inducible nitric oxide synthase; ISO, International Organization for Standardization; $n$-3 LC-PUFA, $n$-3 long-chain PUFA; ScYE, Scizochytrium sp. + yeast extract; TGC, thermal growth coefficient.

* Corresponding author: Dr K. Kousoulaki, email katerina.kousoulaki@nofima.no 
approximately one million tons annually, and the salmon feed industry alone utilises about $50 \%$ of this ${ }^{(28,29)}$. Further sustainable aquaculture growth with lower environmental impacts depends on increasing supplies of alternative marine n-3 LC-PUFA-rich feed ingredients to maintain good fish health and welfare standards and high consumer product quality ${ }^{(30)}$.

Microalgae are recognised as among the most prominent future sustainable sources of $n$-3 LC-PUFA-rich oils ${ }^{(31,32)}$. Mainly phototrophic $^{(33,34)}$, but recently also some heterotrophic ${ }^{(35,36)}$, microalgae products have been tested in aqua feeds with variable performance results. Besides $n$-3 LC-PUFA, microalgae also contain, as other unicellular organisms, bioactive cell wall material compounds such as $\beta$-glucans, and a multitude of other bioactive components, as for instance, $\beta$-carotenes, flavonoids, nucleotides and water-soluble peptides. Those may affect nutrient availability and growth performance, but also enhance the well-being of fish by improving gut health and thus nutrient assimilation and immune competence and thus resistance to pathogens and disease ${ }^{(37-43)}$. Nevertheless, there are still concerns surrounding the viability of using single cell oils in aquaculture, associated with high production costs, high technological development requirement, and limited production capacity of mainly phototrophic microalgae ${ }^{(44,45)}$. In that sense, microalgae are less probable to be used in the near future as a protein source and fishmeal alternative in aqua feeds, as long as other available, far more economic, efficient marine and plant-based high-protein raw materials exist $^{(46-48)}$. Nevertheless, large-scale production of heterotrophic microalgae by established fermentation technology, such as Schizochytrium sp., with high lipid content (55-75\% in DM) and up to $49 \%$ DHA of total lipids is practised today ${ }^{(49)}$. Such products can in the near future target the costefficient supplementation of aqua feeds with $n-3$ LC-PUFA to meet the nutritional requirements of farmed organisms and maintain the health properties of aquaculture products for human consumption.

To date, there is very limited available information on the nutritional quality, digestibility and functional effects of feeding high dietary levels of whole heterotrophic microalgae biomass to Atlantic salmon (Salmo salar). The main objective of the present study was to enrich the existing knowledge on the feasibility to ease the pressure on fish oil as a source of $n$-3 LC-PUFA in Atlantic salmon feeds using DHA-rich Schizochytrium sp. microalgae, maintaining fish health, performance and adequate $n$ - 3 LC-PUFA level in the fillets. Results on n-3 LC-PUFA and SFA levels in salmon fillets, fillet quality parameters: lipid-holding capacity, lipid fat losses during storage and fillet gaping, and Atlantic salmon production performance, gut health and global gene expression are presented.

\section{Materials and methods}

\section{Raw materials, diets and fish experiment}

Four commercially relevant ${ }^{(50)}$ Atlantic salmon diet formulations were created (Table 1) with increasing levels (up to $150 \mathrm{~g} / \mathrm{kg}$ ) spray-dried algae (Schizochytrium sp.) biomass adjusted to $50 \%$ crude lipid content by supplementation of yeast extract (Alltech Inc.) and decreasing levels of supplemental fish oil (down to $0 \mathrm{~g} / \mathrm{kg}$ ). The dietary inclusion levels of ScYE (Scizochytrium sp. + yeast extract) tested were 0, 10, 60 and $150 \mathrm{~g} / \mathrm{kg}$. The dietary formulations were balanced on the basis of calculated digestible protein, energy and amino acids, soluble $\mathrm{P}$ and total EPA + DHA. The experimental diets were produced by extrusion in the same production series, under standard setup conditions at the Feed Technology Center of Nofima in Titlestad, Norway.

Table 1. Dietary formulations in Atlantic salmon (Salmo salar) feeding experiment (raw material content is given in $\mathrm{g} / \mathrm{kg}$ raw material mix)

\begin{tabular}{|c|c|c|c|c|}
\hline Diet... & Diet 1, 0_ScYE & Diet 2, 1_ScYE & Diet 3, 6_ScYE & Diet 4, 15_ScYE \\
\hline Fishmeal & 248 & 248 & & 248 \\
\hline Soya protein concentrate & 180 & 180 & 180 & 180 \\
\hline Maize gluten & 119 & 119 & 117 & 43 \\
\hline Wheat gluten & 60 & 59.5 & 58 & 100 \\
\hline Horse beans & 91.8 & $86 \cdot 8$ & $66 \cdot 7$ & 54.6 \\
\hline Soya lecithin & 5 & 5 & 5 & 5 \\
\hline Rapeseed oil & 75 & 75 & 75 & 152 \\
\hline Fish oil & 153 & 148.5 & 122.4 & \\
\hline $\mathrm{ScYE}^{*}$ & - & 10 & 60 & 150 \\
\hline Inositol & 0.3 & 0.3 & 0.3 & 0.3 \\
\hline Betafin & 5 & 5 & 5 & 5 \\
\hline Mineral premix - P† & $5 \cdot 2$ & $5 \cdot 2$ & $5 \cdot 2$ & $5 \cdot 2$ \\
\hline $\mathrm{NaH}_{2} \mathrm{PO}_{4}$ & $26 \cdot 3$ & $26 \cdot 3$ & $26 \cdot 0$ & $25 \cdot 6$ \\
\hline Vitamin mix $\dagger$ & 20 & 20 & 20 & 20 \\
\hline Lysine & 2.5 & 2.5 & 2.5 & 2.5 \\
\hline Methionine & 7.9 & 7.9 & 7.9 & 7.9 \\
\hline Astaxanthine (10\%) & 0.5 & 0.5 & 0.5 & 0.5 \\
\hline Yttrium oxide & 0.5 & 0.5 & 0.5 & 0.5 \\
\hline Sum & 1000 & 1000 & 1000 & 1000 \\
\hline
\end{tabular}

0_ScYE, $0 \mathrm{~g} / \mathrm{kg}$ Scizochytrium sp. + yeast extract (control); 1_ScYE, 10 g/kg Scizochytrium sp. + yeast extract; 6_ScYE, 60 g/kg Scizochytrium sp. + yeast extract; 15_ScYE, $150 \mathrm{~g} / \mathrm{kg}$ Scizochytrium sp. + yeast extract.

* Heterotrophically produced Scizochytrium sp., spray dried and balanced to $500 \mathrm{~g} / \mathrm{kg}$ total fat by yeast extract (Alltech Inc.).

† Providing in the final diet: $3000 \mathrm{lU}$ vitamin $\mathrm{D}_{3}, 160 \mathrm{mg} / \mathrm{kg}$ vitamin $\mathrm{E}, 20 \mathrm{mg} / \mathrm{kg}$ vitamin $\mathrm{K}_{3}, 200 \mathrm{mg} / \mathrm{kg}$ vitamin C, $20 \mathrm{mg} / \mathrm{kg}$ vitamin B, $30 \mathrm{mg} / \mathrm{kg}$ vitamin $\mathrm{B}_{2}, 25 \mathrm{mg} / \mathrm{kg}$ vitamin $\mathrm{B}_{6}$, $0.05 \mathrm{mg} / \mathrm{kg}$ vitamin $\mathrm{B}_{12}, 60 \mathrm{mg} / \mathrm{kg}$ vitamin $\mathrm{B}_{5}, 10 \mathrm{mg} / \mathrm{kg}$ folic acid, $200 \mathrm{mg} / \mathrm{kg}$ vitamin $\mathrm{B}_{3}, 1 \mathrm{mg} / \mathrm{kg}$ vitamin $\mathrm{B}_{7}, 92.31 \mathrm{mg} / \mathrm{kg} \mathrm{MnSO} \mathrm{M}_{4}+\mathrm{H}_{2} \mathrm{O}, 3125 \mathrm{mg} / \mathrm{kg} \mathrm{MgHPO} \mathrm{M}_{4}+3 \mathrm{H}_{2} \mathrm{O}$, $182.4 \mathrm{mg} / \mathrm{kg} \mathrm{FeSO}{ }_{4}+\mathrm{H}_{2} \mathrm{O}, 352.9 \mathrm{mg} / \mathrm{kg} \mathrm{ZnSO}{ }_{4}+\mathrm{H}_{2} \mathrm{O}, 23.62 \mathrm{mg} / \mathrm{kg} \mathrm{CuSO}{ }_{4}+\mathrm{H}_{2} \mathrm{O}, 1413 \mathrm{mg} / \mathrm{kg} \mathrm{K}_{2} \mathrm{CO}_{3}$ and 6.67 mg/kg Se. 
Unfed (24 h) Atlantic salmon smolts from Sunndalsøra, Norway, of $213 \mathrm{~g}$ initial body weight, were used for the current trial which lasted for 12 weeks. Groups of between ten and twenty fish were bulk weighed and transferred to each one of twelve experimental tanks to end up with forty fish per tank $\left(8 \mathrm{~kg} / \mathrm{m}^{3}\right.$ fish stocking density). The mean water temperature during the trial was $10 \cdot 2^{\circ} \mathrm{C}$, water flow was continuous (30 litres/min, $180 \% / \mathrm{h}$ ), and water salinity ranged between 32 and 33 parts per thousand. The water system was flow-through using UV-treated filtrated seawater from $40 \mathrm{~m}$ depth. The fish were first fed the day following the start of the trial, in gradually increasing amounts in order to determine the satiation feeding levels of each group. Fish were fed continuously in satiation (115.6\% of ad libitum levels) using automatic feeders until the moment of sampling for each individual tank. Uneaten pellets were collected daily to monitor the daily feed intake of each experimental population. Five fish per tank were randomly removed at the trial start and also after 6 weeks for total lipid and fatty acid analysis in Norwegian quality cut fillet samples. At the trial end, five non-stripped randomly selected fish, excluding too big, too small fish or fish with empty stomachs, were used for the sampling of blood, Norwegian quality cut fillet and internal organs (liver and intestine) for further chemical analyses and biological studies. All other fish from each tank were stripped and their faeces separated from urine, collected in a pre-weighed box per tank, and frozen immediately at $-20{ }^{\circ} \mathrm{C}$ prior to further analyses.

\section{Chemical composition analyses}

Crude protein in diets and faeces was determined by the Kjeldahl method $(\mathrm{N} \times 6 \cdot 25)$ (ISO (International Organization for Standardization) 5983-1997). Moisture (ISO 6496-1999) and ash (ISO 5984-2002) were determined gravimetrically after drying pre-weighed samples in porcelain cups at $105^{\circ} \mathrm{C}$ for $24 \mathrm{~h}$ and then incinerating the dried samples at $500{ }^{\circ} \mathrm{C}$ for $12 \mathrm{~h}$, respectively. Total lipid in raw materials, diets and the body tissues was quantified by the Bligh \& Dyer extraction method ${ }^{(51)}$. Dietary gross energy was determined in a Parr adiabatic bomb calorimeter. For total amino acid profile determination, samples were hydrolysed in $6 \mathrm{~m}-\mathrm{HCl}$ for $22 \mathrm{~h}$ at $110^{\circ} \mathrm{C}$ and analysed by HPLC using a fluorescence technique for detection $^{(52)}$. Total $\mathrm{P}$ was determined by a spectrophotometric method (ISO 6491-1998). The water-soluble fraction of the diets was extracted with boiling water. The extract was then filtered using paper filter, and the crude protein content in the water phase was determined by the Kjeldahl method. Analysis of fatty acid composition was realised in Bligh \& Dyer $^{(51)}$ extracts. Preparation of fatty acid methyl esters (FAME) was done according to AOCS Official Method Ce 1b-89. The GC analyses was conducted on a Trace GC gas chromatograph (Thermo Fisher Scientific) with a flame ionisation detector (GC-FID), equipped with a $60 \mathrm{~m} \times 0.25 \mathrm{~mm}$ BPX-70 cyanopropyl column with $0.25 \mu \mathrm{m}$ film thickness (SGE Analytical Science). He 4.6 was used as the mobile phase under the pressure of 2.60 bar. The injector temperature was $250^{\circ} \mathrm{C}$ and the detector temperature was $260^{\circ} \mathrm{C}$. The oven was programmed as follows: $60^{\circ} \mathrm{C}$ for $4 \mathrm{~min}$,
$30{ }^{\circ} \mathrm{C} / \mathrm{min}$ to $164^{\circ} \mathrm{C}$, and then $1.0^{\circ} \mathrm{C} / \mathrm{min}$ to $213^{\circ} \mathrm{C}$, and $100{ }^{\circ} \mathrm{C} / \mathrm{min}$ to $250^{\circ} \mathrm{C}$ where the temperature was held for $10 \mathrm{~min}$. The sample solution $(3 \cdot 0 \mu \mathrm{l})$ was injected splitless and the split was opened after 2 min. The FAME were identified by comparing the elution pattern and relative retention time with the reference FAME mixture (GLC-793; Nu-Chek Prep Inc.). Chromatographic peak areas were corrected by empirical response factors calculated from the areas of the GLC-793 mixture. Fatty acid composition was calculated by using 23 : 0 FAME as the internal standard and reported on a sample basis as g/100 g FAME. All analyses were performed in duplicate. If differences between parallels exceeded standardised values, new duplicate analyses were carried out according to accredited procedures (Table 2).

Salmon plasma leptin hormone levels were measured using the Fish (salmon) leptin (LEP) ELISA kit (Cusabio) following the manufacturer's protocol. Absorbance was measured at $450 \mathrm{~nm}$ in a Spectrostar Nano microplate reader from BMG LabTech $\mathrm{GmbH}$. Plasma creatine kinase (CK) is a measure of muscle degradation. As an indicator of muscle damage, enzymic activity of CK was analysed spectrophotometrically in salmon plasma (Avida ${ }^{\circledR} 1650$ analytical instrument; Bayer) ${ }^{(53)}$.

The apparent digestibility coefficient (ADC) of nutrients and energy in the test diets was calculated from the following formula: $\mathrm{ADC}=100-100 \times \mathrm{Yd} \times \mathrm{Nf} / \mathrm{Nd} / \mathrm{Yf}$, were $\mathrm{d}$ is diet, $\mathrm{f}$ is faeces, $\mathrm{Y}$ is yttrium content and $\mathrm{N}$ is nutrient content. Thermal growth coefficient (TGC) was calculated from the following formula: TGC $=\left(\mathrm{w}_{2}^{1 / 3}-\mathrm{w}_{1}^{1 / 3}\right) \times 1000 / \sum(\mathrm{t} \times$ feeding days $)$, where $\sum(\mathrm{t} \times$ feeding days $)$ is the sum of water temperatures $\left({ }^{\circ} \mathrm{C}\right)$ for every feeding day in the experiment ${ }^{(54)}$. Feed intake was calculated as the mean feed consumption per fish per day as $\%$ of the daily fish body weight. The daily fish body weight was calculated using daily TGC values equal to the overall TGC of each tank. Feed conversion ratio (FCR) is feed consumed/biomass increase. Protein efficiency ratio is fish weight gain/protein consumption. Condition factor is (fish weight $(\mathrm{g}) /$ fish fork length $\left.{ }^{3}\right) \times 1000$. Dress-out percentage is (gutted fish weight/whole fish weight) $\times 100$. Hepatosomatic index (HSI) is $100 \times$ (liver weight/whole fish weight).

\section{Fish fillet technical quality}

Fish fillet technical quality was evaluated in terms of fatty acid composition, liquid-holding capacity, gaping and texture. Liquid-holding capacity was analysed as the ability of a standardised muscle sample $(15 \mathrm{~g})$ to retain water and fat, respectively, during storage and was analysed as weight decreased during thawing the muscle $(75 \mathrm{~g})$ at $20{ }^{\circ} \mathrm{C}$ for $20 \mathrm{~h}^{(55)}$. Fillet gaping was analysed according to a visual scale ranging from 0 to 5 , where 0 corresponds to no gaping and score 5 extreme gaping $^{(56)}$. Instrumental analyses of salmon fillets were performed using a Texture analyser, TA-XT2 (Stable Micro System Ltd) equipped with a flat-ended cylindrical probe $(12.5 \mathrm{~mm}$ diameter, type $\mathrm{p} / 0.5)$ and a $30 \mathrm{~kg}$ load cell. Firmness predicted using this method correlates well with sensory assessment of firmness of raw and smoked salmon fillets ${ }^{(57)}$ 
Table 2. Experimental raw material and diet chemical composition, given in $\mathrm{g} / \mathrm{kg}$ diet as-is or as-fed, respectively, for proximate composition and dietary $\mathrm{ScYE}^{*}$ content, in $\mathrm{kJ} / \mathrm{g}$ diet as-fed for dietary crude energy content, and in $\mathrm{g} / \mathrm{kg}$ Bligh and Dyer extract for fatty acid (FA) and lipid class composition

\begin{tabular}{|c|c|c|c|c|c|}
\hline & ScYE & Diet 1, 0_ScYE & Diet 2, 1_ScYE & Diet 3, 6_ScYE & Diet 4, 15_ScYE \\
\hline Supplemental dietary fish oil & & 153 & 148.5 & 122.4 & 0 \\
\hline Dietary ScYE & & 0 & 10 & 60 & 150 \\
\hline \multicolumn{6}{|l|}{ Proximate composition } \\
\hline Crude protein & 178 & 443 & 437 & 425 & 445 \\
\hline Moisture & 27 & 81 & 78 & 73 & 77 \\
\hline Crude ash & 37 & 74 & 75 & 73 & 76 \\
\hline Total lipid & 544 & 272 & 281 & 305 & 278 \\
\hline Gross energy & & $227 \cdot 1$ & 229.4 & $236 \cdot 6$ & $230 \cdot 3$ \\
\hline \multicolumn{6}{|l|}{ Lipid fatty acids } \\
\hline Sum SFA & 577 & 163 & 167 & 212 & 244 \\
\hline Sum MUFA & 4 & 468 & 452 & 448 & 378 \\
\hline Sum PUFA (n-6) FA & 7 & 91 & 88 & 90 & 120 \\
\hline Sum PUFA (n-3) FA & 264 & 167 & 165 & 181 & 147 \\
\hline Sum PUFA FA & 271 & 263 & 258 & 275 & 267 \\
\hline Sum FA & 852 & 894 & 877 & 935 & 889 \\
\hline $14: 0$ & 44 & 39 & 38 & 39 & 20 \\
\hline $16: 0$ & 515 & 104 & 109 & 151 & 202 \\
\hline $18: 0$ & 15 & 17 & 17 & 18 & 16 \\
\hline $20: 0$ & 2 & 2 & 02 & 3 & 04 \\
\hline $22: 0$ & 1 & 1 & 01 & 1 & 2 \\
\hline $16: 1 n-7$ & 1 & 32 & 30 & 28 & 7 \\
\hline $18: 1(n-9)+(n-7)+(n-5)$ & 3 & 263 & 253 & 265 & 335 \\
\hline $20: 1(n-9)+(n-7)$ & $<1$ & 74 & 72 & 67 & 18 \\
\hline $22: 1(n-11)+(n-9)+(n-7)$ & $<1$ & 95 & 93 & 85 & 17 \\
\hline $24: 1 n-9$ & $<1$ & 4 & 4 & 3 & 1 \\
\hline $16: 2 n-4$ & $<1$ & 3 & 3 & 2 & $<1$ \\
\hline $16: 3 n-4$ & $<1$ & 2 & 2 & 2 & $<1$ \\
\hline $18: 2 n-6$ & 6 & 88 & 85 & 88 & 120 \\
\hline $18: 3 n-6$ & $<1$ & $<1$ & $<1$ & $<1$ & $<1$ \\
\hline $20: 2 n-6$ & $<1$ & 1 & 1 & 1 & $<1$ \\
\hline $20: 3 n-6$ & 1 & $<1$ & $<1$ & $<1$ & $<1$ \\
\hline $20: 4 n-6$ & $<1$ & 2 & 2 & 1 & $<1$ \\
\hline $22: 4 n-6$ & $<1$ & $<1$ & $<1$ & $<1$ & $<1$ \\
\hline $18: 3 n-3$ & $<1$ & 29 & 28 & 30 & 40 \\
\hline $18: 4 n-3$ & $<1$ & 18 & 17 & 16 & 3 \\
\hline $20: 3 n-3$ & $<1$ & 1 & $<1$ & 1 & $<1$ \\
\hline $20: 4 n-3$ & 4 & 4 & 4 & 4 & 1 \\
\hline $20: 5 n-3$ (EPA) & 2 & 45 & 43 & 40 & 11 \\
\hline $21: 5 n-3$ & $<1$ & 2 & 2 & 2 & $<1$ \\
\hline $22: 5 n-3$ & $<1$ & 5 & 5 & 4 & 1 \\
\hline $22: 6 n-3(\mathrm{DHA})$ & 258 & 63 & 66 & 84 & 91 \\
\hline \multicolumn{6}{|l|}{ Lipid classes } \\
\hline TAG & 870 & & & & \\
\hline Diacylglycerol & $<5$ & & & & \\
\hline Monoacylglycerol & $<10$ & & & & \\
\hline NEFA & 28 & & & & \\
\hline Sterols & 14 & & & & \\
\hline Total polar lipids & $<10$ & & & & \\
\hline
\end{tabular}

0_ScYE, $0 \mathrm{~g} / \mathrm{kg}$ Scizochytrium sp. + yeast extract (control); 1_ScYE, $10 \mathrm{~g} / \mathrm{kg}$ Scizochytrium sp. + yeast extract; 6_ScYE, $60 \mathrm{~g} / \mathrm{kg}$ Scizochytrium sp. + yeast extract; 15_ScYE, $150 \mathrm{~g} / \mathrm{kg}$ Scizochytrium sp. + yeast extract.

${ }^{*}$ Heterotrophically produced Scizochytrium sp., spray dried and balanced to $500 \mathrm{~g} / \mathrm{kg}$ total fat by yeast extract (Alltech Inc.)

\section{Microscopic analysis of intestinal tissue}

For microscopic analysis, intestinal tissue was sampled just aft of the pyloric caeca. After removal of the intestinal content by rinsing with $1 \times \mathrm{PBS}$, fixation was achieved in $4 \%$ paraformaldehyde (PFA). Sampled tissue was dehydrated and embedded in polyester wax and sectioned at $7 \mu \mathrm{m}^{(58)}$. Intestinal morphology was assessed by Phalloidin and wheat germ agglutinin (WGA) staining, which visualises $\mathrm{F}$-actin in the tight junctions and connective tissue/mucus, respectively. Samples were also analysed by immunofluorescence to assess the effect of dietary level of ScYE upon oxidative stress using an antibody against inducible nitric oxide synthase (iNOS) ${ }^{(59)}$. This protein is a key player in the intestinal immune system and controls inflammatory cytokines such as TNF $\alpha$. As ScYE was a new raw material for salmon nutrition we were unaware of the anticipated effects and the scope of the microscopic analyses was to obtain indications of possible effects. Thus only five fish per dietary treatment were analysed.

\section{Microarray analyses}

RNA was extracted using PureLink RNA Mini kits according to the manufacturer's protocol (Invitrogen). Concentration of 
total RNA (NanoDrop 1000 Spectrometer; Thermo Scientific) and RNA integrity were measured (Agilent 2100 Bioanalyser with RNA Nano kits; Agilent Technologies). Samples with RNA integrity number (RIN) $>8$ were accepted for analyses. Multiple gene expression profiling was performed with Nofima's Atlantic salmon $15 \mathrm{k}$ oligonucleotide microarray SIQ6 (GEO Omnibus GPL16555) produced by Agilent Technologies. Two-colour hybridisations were performed. Analyses included four replicates from each study group; in total sixteen microarrays were used. RNA amplification, labelling and fragmentation were performed using the two-colour low-input quick AMP labelling kit and gene expression Hybridisation kit following the manufacturer's instructions (Agilent Technologies). The input of total RNA in each reaction was $100 \mathrm{ng}$. Test samples and reference (equalised mixture of all samples) were labelled with $\mathrm{Cy} 5$ and $\mathrm{Cy} 3$ (cyanine), respectively. Overnight hybridisation $\left(17 \mathrm{~h} ; 65^{\circ} \mathrm{C}\right.$; rotation speed of $\left.10 \mathrm{rpm}\right)$ was executed in an oven (Agilent Technologies). The slides were washed with Gene Expression Wash Buffers 1 and 2 and scanned with a GenePix 4100A (Molecular Devices) at $5 \mu \mathrm{m}$ resolution. The GenePix Pro software (version 6.1) was used for spot-to-grid alignment, feature extraction and quantification. Assessment of spot quality was done with GenePix flags. Nofima's bioinformatics package STARS ${ }^{(60)}$ was used for data processing and mining. After filtration of low-quality spots, LOWESS (locally weighted scatterplot smoothing ) normalisation of $\log _{2}$-expression ratios (ER) was done. The differentially expressed genes were selected by criteria by difference from the control: $\log _{2}$-ER $>|0.8| \quad(1.75$-fold) and $P<0.05$ (online Supplementary Table S1).

\section{Statistics}

Data were tested for normality using a KolomogorovSmirnov test and homogeneity of variance using Levene's test, and when necessary, transformed via arcsine function. One-way ANOVA was used for the statistical analyses of the whole dataset, whereas two-way ANOVA and correlation statistical analyses were performed in addition of the fillet fatty acid composition data to test effects of time and diet. The statistical analyses presented were performed using Microsoft Excel and SPSS 10.0 for Windows. When significant differences among groups were identified, multiple comparisons among means were made using the Tukey test. Differences were considered significant at the level of $P<0 \cdot 05$.

\section{Results}

\section{General fish performance}

Fish survival, feed intake, feed conversion and protein efficiency rates were similar among the different treatments (Table 3). Fish fed $1 \%$ ScYE in the diet had the highest body growth rate significantly only when compared with fish fed in treatment 15_ScYE. There was a significant positive correlation between feed intake and FCR $\left(R^{2} 0.79 ; n\right.$ 12), but not between feed intake and growth. There were no significant effects of ScYE dietary incorporation on liver size (HSI) or fish condition factor. Fish fed the diet 15_ScYE had significantly higher fillet yield (dress-out percentage) compared with the other treatments. Significantly reduced postprandial leptin

Table 3. Performance, biometrics and postprandial plasma leptin of Atlantic salmon (Salmo salar) fed diets with increasing levels of ScYE* and decreasing levels of fish oil

(Mean values with their standard errors; $n 3$, except for plasma leptin: $n 15)$

\begin{tabular}{|c|c|c|c|c|c|}
\hline Treatment... & 0_ScYE & 1_ScYE & 6_ScYE & 15_ScYE & SEM \\
\hline Supplemental dietary fish oil (g/kg diet) & 153 & 148.5 & 122.4 & 0 & \\
\hline Dietary ScYE (g/kg diet) & 0 & 10 & 60 & 150 & \\
\hline Start fish number & 40 & 40 & 40 & 40 & 0 \\
\hline Total mortality (\%) & 2.5 & 0.0 & 0.8 & 0.8 & 0.6 \\
\hline Initial fish body weight (g) & 213 & 213 & 213 & 213 & 0 \\
\hline Final fish body weight $(\mathrm{g})$ & $824^{a, b}$ & $851^{\mathrm{b}}$ & $819^{a, b}$ & $797^{\mathrm{a}}$ & 7 \\
\hline Total feed intake $(\mathrm{kg})$ & 18.4 & $21 \cdot 2$ & 21.0 & $19 \cdot 2$ & 0.6 \\
\hline FI† (\% metabolic body weight/d) & 1.39 & 1.53 & 1.54 & 1.45 & 0.03 \\
\hline FCR $\ddagger$ & 0.78 & 0.83 & 0.88 & 0.83 & 0.02 \\
\hline TGC§ $(\times 1000)$ & $4.03^{a, b}$ & $4 \cdot 15^{\mathrm{b}}$ & $4 \cdot 01^{\mathrm{a}, \mathrm{b}}$ & $3.91^{a}$ & 0.03 \\
\hline PERII & 2.89 & $2 \cdot 76$ & 2.71 & $2 \cdot 73$ & 0.07 \\
\hline CF』 & 1.46 & 1.45 & 1.48 & 1.41 & 0.01 \\
\hline $\mathrm{D} \%$ ** & $87.9^{\mathrm{a}}$ & $87.8^{\mathrm{a}}$ & $87 \cdot 3^{\mathrm{a}}$ & $88.7^{\mathrm{b}}$ & 0.2 \\
\hline HSIt† & 1.54 & 1.54 & 1.42 & 1.48 & 0.02 \\
\hline Salmon postprandial plasma leptin (ng leptin/ml plasma) & $63 \cdot 7^{\mathrm{b}}$ & $55 \cdot 7^{\mathrm{a}}$ & $64 \cdot 4^{\mathrm{b}}$ & $69 \cdot 1^{\mathrm{b}}$ & 1.4 \\
\hline
\end{tabular}

0_ScYE, $0 \mathrm{~g} / \mathrm{kg}$ Scizochytrium sp. + yeast extract (control); 1_ScYE, $10 \mathrm{~g} / \mathrm{kg}$ Scizochytrium sp. + yeast extract; $6 \_$ScYE, $60 \mathrm{~g} / \mathrm{kg}$ Scizochytrium sp. + yeast extract; 15_ScYE, $150 \mathrm{~g} / \mathrm{kg}$ Scizochytrium sp. + yeast extract; FI, feed intake; FCR, feed conversion ratio; TGC, thermal growth coefficient; PER, protein efficiency ratio; CF, condition factor; $\mathrm{D} \%$, dress-out percentage; HSI, hepatosomatic index.

a,b Mean values within a row with unlike superscript letters were significantly different $(P<0.05$; one-way ANOVA as separated by Tukey's post hoc test).

* Heterotrophically produced Scizochytrium sp., spray dried and balanced to $500 \mathrm{~g} / \mathrm{kg}$ total fat by yeast extract (Alltech Inc.).

$\dagger$ FI rate is the mean feed consumption per fish per d expressed as percentage of the daily fish body weight. The daily fish body weight was calculated using daily specific growth rate values equal to the overall specific growth rate of each tank.

$\ddagger$ FCR is total feed consumed/total fish biomass increase.

$\S \mathrm{TGC}=\left(\mathrm{w}_{2}^{1 / 3}-\mathrm{w}_{1}^{1 / 3}\right) \times 1000 / \sum(\mathrm{t} \times$ feeding days $)$, where $\Sigma(\mathrm{t} \times$ feeding days $)$ is the sum of water temperatures $\left({ }^{\circ} \mathrm{C}\right)$ for every feeding day in the experiment ${ }^{(59)}$

II PER is fish weight gain/protein consumption.

ๆ $\mathrm{CF}=\left(\right.$ fish weight $(\mathrm{g}) /$ fish fork length $\left.{ }^{3}\right) \times 1000$.

** $\mathrm{D} \%=$ (gutted fish weight/whole fish weight) $\times 100$.

†† $\mathrm{HSI}=\%$ of liver weight/whole fish weight. 
Table 4. Fillet (Norwegian quality cut) technical quality of Atlantic salmon (Salmo salar) fed diets with increasing levels of ScYE* and decreasing levels of fish oil

(Mean values with their standard errors; $n$ 3)

\begin{tabular}{|c|c|c|c|c|c|}
\hline Treatment... & 0_ScYE & 1_ScYE & 6_ScYE & 15_ScYE & SEM \\
\hline Supplemental dietary fish oil ( $\mathrm{g} / \mathrm{kg}$ diet) & 153 & 148.5 & 122.4 & 0 & \\
\hline Dietary ScYE (g/kg diet) & 0 & 10 & 60 & 150 & \\
\hline Gaping score & 0.7 & 0.9 & 1.1 & 1.1 & 0.2 \\
\hline Firmness (Newtons) & 3.5 & 3.5 & 3.5 & 3.6 & 0.1 \\
\hline Liquid loss (\%) & $9 \cdot 3$ & $10 \cdot 2$ & 9.4 & $10 \cdot 6$ & 1.0 \\
\hline
\end{tabular}

0_ScYE, 0 g/kg Scizochytrium sp. + yeast extract (control); 1_ScYE, 10 g/kg Scizochytrium sp. + yeast extract; $6 \_S c Y E, 60$ g/kg Scizochytrium sp. + yeast extract; 15_ScYE, $150 \mathrm{~g} / \mathrm{kg}$ Scizochytrium sp. + yeast extract.

* Heterotrophically produced Scizochytrium sp., spray dried and balanced to $500 \mathrm{~g} / \mathrm{kg}$ total fat by yeast extract (Alltech Inc.).

levels were analysed in the blood plasma of the fish in treatment 1_ScYE compared with the other three treatments.

\section{Salmon fillet (Norwegian quality cut) technical quality}

The technical quality of the salmon fillets at the end of the experiment was similar in all dietary treatments (Table 4). The degree of salmon fillet gaping was generally low in all experimental treatments, averaging score 1. Gaping at such a low level does not cause problems during filleting and/or processing. Instrument fillet texture analyses revealed no texture abnormalities and no significant differences were observed between dietary treatments. The results showed no significant variation in liquid loss during thawing between dietary treatments.

\section{Salmon fillet (Norwegian quality cut) fatty acid composition}

The salmon Norwegian quality cut fillet lipid and fatty acid contents at the experiment start and after 6 and 12 weeks of feeding with the experimental diets are presented in Table 5 . The total lipid levels in the fillets increased from $39 \mathrm{~g} / \mathrm{kg}$ at trial start to $110-120 \mathrm{~g} / \mathrm{kg}$ at trial end, and, as a consequence, the fillet levels of the different fatty acids supplemented by the diet also increased accordingly. At the end of the trial, no significant differences were observed in total fillet lipid levels among the fish fed the control and the ScYE-supplemented diets. In general terms, there was no difference between control (0_ScYE), 1_ScYE and 6_ScYE treatments, except for the higher DHA levels in treatment 6_ScYE and lower total fatty acid levels in the control fish. Fish fillets in treatment 15_ScYE had higher total $n-6$ PUFA (significantly also for $18: 2 n-6$ and $20: 2 n-6), 18: 3 n-3$ and $20: 0$ levels than the control and lower levels of EPA, $14: 0,16: 1,16: 2 n-4,18: 4 n-3,20$ : 1, $20: 4 n-3,21: 5 n-3,22: 5 n-3,22: 1$ and $24: 1 n-9$ compared with all other treatments.

\section{Apparent digestibility coefficient of dietary energy and nutrients}

Dietary protein ADC was similar between the control and all ScYE-supplemented diets in Atlantic salmon (Table 6). At the 6 and $15 \%$ ScYE dietary supplementation levels lipid and total fatty acid ADC significantly reduced compared with the control and $1 \%$ ScYE supplementation, mainly due to lower digestibility of all analysed SFA. In 15_ScYE, ADC of DHA (98.1 \%), total $n$-3 PUFA (98.6 \%) and total PUFA (98.7\%) was $1 \%$ lower $(P<0.001)$ compared with all others treatments. The ADC of MUFA was $0 \cdot 3-0.5 \%$ higher in the ScYE supplemented fatty acids compared with the control $(P<0 \cdot 01)$. Total ADC of dietary energy was highest in the 1_ScYE and lowest in the 15_ScYE treatment.

\section{Microarray analyses}

The transcriptomic changes caused by the test diets were small as witnessed by the numbers of differentially expressed genes (Fig. 1(A)). A few genes passed the selection threshold in two groups and only one gene with unknown functions was differentially expressed in all groups. Nonetheless, a suite of genes showed either similar profiles across all groups or dose responses; examples are in Table 7. p53 (up-regulated) plays a key part in the control of cellular growth and apoptosis, while sesn 1 (down-regulated) stimulates growth arrest in response to diverse stressors. Sh3 bgrl3 is involved in protection against oxidative stress and abcg $2 a$ expels toxic compounds from cells. Up-regulated $p p d p f$ controls differentiation of exocrine cells. Only one gene (mlyc, $d)$ takes part in the biosynthesis of fatty acids ${ }^{(61)}$. Common profiles were shown by erythrocytespecific genes: their expression decreased at low levels of ScYE, while at high levels differences from control were minor (Fig. 1(B)).

\section{Microscopic analysis of intestinal tissue and plasma creatine kinase}

Following histological examination of each feeding treatment (n 5), ScYE supplementation up to $15 \%$ in the diet did not induce enteritis or abnormal intestinal morphology. However, an increasing dietary level of ScYE induced an increased number of slime cells as well as an increased oxidative stress response in the intestine of Atlantic salmon (Fig 2(A)-(F)). The control fish showed normal intestinal morphology and goblet cell numbers, as shown stained by wheat germ agglutinin (WGA), and modest levels of iNOS activity (Fig. 2(A): arrow head). Dietary inclusion of $1 \% \mathrm{ScYE}$ increased iNOS activity moderately (Fig. 2(B): arrow head) and there appeared to be somewhat more goblet cells (Fig. 2(B): arrow). In fish fed 6 $\% \mathrm{ScYE}$ in the diet, up-regulation of iNOS was evident at the base of the intestine (Fig. 2(C): arrow head), whereas in 


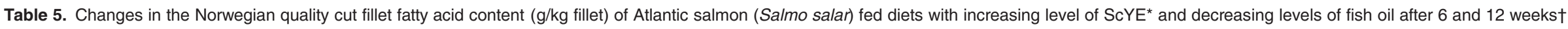
(Mean values with their standard errors)

\begin{tabular}{|c|c|c|c|c|c|c|c|c|c|c|c|c|c|c|c|}
\hline \multirow{2}{*}{$\begin{array}{l}\text { Time... } \\
\text { Treatment... }\end{array}$} & \multicolumn{2}{|c|}{0} & \multicolumn{5}{|c|}{6 weeks } & \multicolumn{5}{|c|}{12 weeks } & \multicolumn{3}{|c|}{ Two-way ANOVA $(P)$} \\
\hline & Start & SEM $(n 2)$ & O_ScYE & 1_ScYE & 6_ScYE & 15_ScYE & $\operatorname{SEM}(n 12)$ & 0_ScYE & 1_ScYE & 6_ScYE & 15_ScYE & SEM $(n 12)$ & Diet & Time & Diet $x$ time \\
\hline Total lipids (Bligh and Dyer) & $39.0^{\mathrm{a}}$ & $2 \cdot 0$ & $88 \cdot 7^{b, c}$ & $90 \cdot 7^{\mathrm{b}, \mathrm{c}}$ & $85.7^{\mathrm{b}}$ & $83.0^{\mathrm{b}}$ & 2.8 & $117 \cdot 0^{\mathrm{c}, \mathrm{d}}$ & $123.0^{d}$ & $122 \cdot 3^{d}$ & $109 \cdot 0^{b, c, d}$ & 2.9 & NS & 0.001 & NS \\
\hline $14: 0$ & $1.32^{\mathrm{a}}$ & 0.03 & $3.02^{c, d}$ & $3.02^{c, d}$ & $2 \cdot 83^{b, c}$ & $1.74^{\mathrm{a}}$ & 0.19 & $3.90^{\mathrm{c}, \mathrm{d}}$ & $4.09^{d}$ & $3.93^{\mathrm{d}}$ & $1.92^{a, b}$ & 0.28 & 0.001 & 0.001 & NS \\
\hline $16: 0$ & $5 \cdot 16^{\mathrm{a}}$ & 0.09 & $10 \cdot 82^{\mathrm{b}}$ & $10.93^{\mathrm{b}, \mathrm{c}}$ & $11.28^{\mathrm{b}, \mathrm{c}}$ & $11.82^{\mathrm{bc}}$ & 0.37 & $13.96^{\mathrm{b}, \mathrm{c}, \mathrm{d}}$ & $14.81^{\mathrm{c}, \mathrm{d}}$ & $16 \cdot 35^{\mathrm{d}}$ & $16 \cdot 35^{d}$ & 0.44 & NS & 0.001 & NS \\
\hline $16: 1 n-7$ & $1.25^{\mathrm{a}}$ & 0.02 & $2 \cdot 76^{\mathrm{c}, \mathrm{d}}$ & $2 \cdot 72^{\mathrm{c}, \mathrm{d}}$ & $2 \cdot 49^{\mathrm{b}, \mathrm{c}}$ & $1.44^{\mathrm{a}}$ & 0.18 & $3.67^{\mathrm{d}, \mathrm{e}}$ & $3.77^{e}$ & $3.52^{d}$ & $1.56^{\mathrm{a}, \mathrm{b}}$ & 0.29 & 0.001 & 0.001 & 0.05 \\
\hline $16: 2 n-4$ & $0.08^{\mathrm{a}}$ & 0.00 & $0 \cdot 18^{\mathrm{b}, \mathrm{c}}$ & $0.18^{\mathrm{b}, \mathrm{c}}$ & $0.17^{b, c}$ & $0.08^{\mathrm{a}}$ & 0.01 & $0.23^{c}$ & $0.25^{\mathrm{c}}$ & $0.24^{\mathrm{C}}$ & $0.12^{\mathrm{a}, \mathrm{b}}$ & 0.01 & 0.001 & 0.001 & - \\
\hline $16: 3 n-4$ & $0.04^{\mathrm{a}}$ & 0.00 & $0.09^{b, c}$ & $0.09^{b, c, d}$ & $0.09^{b}$ & $0.08^{\mathrm{b}}$ & 0.00 & $0 \cdot 12^{\mathrm{b}, \mathrm{c}, \mathrm{d}}$ & $0.12^{\mathrm{d}}$ & $0 \cdot 12^{c, d}$ & $0 \cdot 11^{\mathrm{b}, \mathrm{c}, \mathrm{d}}$ & 0.00 & NS & 0.001 & - \\
\hline $18: 0$ & $0.97^{\mathrm{a}}$ & 0.01 & $2.04^{b}$ & $2.09^{b, c}$ & $1.92^{\mathrm{b}}$ & $1.93^{\mathrm{b}}$ & 0.06 & $2.97^{\mathrm{d}}$ & $3.03^{d}$ & $3.02^{d}$ & $2 \cdot 83^{c, d}$ & 0.07 & NS & 0.001 & NS \\
\hline $18: 1(n-9)+(n-7)+(n-5)$ & $9.09^{\mathrm{a}}$ & 0.21 & $23.76^{\mathrm{b}}$ & $23 \cdot 82^{\mathrm{b}}$ & $22 \cdot 69^{b}$ & $26 \cdot 24^{\mathrm{b}, \mathrm{c}}$ & 0.87 & $33.27^{\mathrm{c}, \mathrm{d}}$ & $34.51^{c, d}$ & $35.02^{d}$ & $38.76^{d}$ & 0.93 & NS & 0.001 & 0.1 \\
\hline $18: 2 n-6$ & $2 \cdot 18^{\mathrm{a}}$ & 0.07 & $6.61^{\mathrm{b}, \mathrm{c}}$ & $6.68^{b, c}$ & $6.44^{\mathrm{b}}$ & $7.98^{\mathrm{b}, \mathrm{c}}$ & 0.29 & $8.99^{\mathrm{c}, \mathrm{d}}$ & $9.46^{\mathrm{d}, \mathrm{e}}$ & $9.76^{\mathrm{d}, \mathrm{e}}$ & $11.60^{\mathrm{e}}$ & 0.35 & 0.001 & 0.01 & 0.05 \\
\hline $18: 3 n-3$ & $0.84^{\mathrm{a}}$ & 0.02 & $2.07^{b}$ & $2 \cdot 15^{\mathrm{b}}$ & $2 \cdot 12^{\mathrm{b}}$ & $2.52^{b, c}$ & 0.09 & $2 \cdot 73^{b, c}$ & $2 \cdot 91^{c, d}$ & $3.02^{c, d}$ & $3.55^{\mathrm{d}}$ & 0.11 & 0.01 & 0.001 & 0.01 \\
\hline $18: 3 n-6$ & $0.04^{\mathrm{a}}$ & 0.00 & $0.09^{b, c}$ & $0.09^{b, c, d}$ & $0.09^{b}$ & $0.08^{\mathrm{b}}$ & 0.00 & $0 \cdot 12^{\mathrm{b}, \mathrm{c}, \mathrm{d}}$ & $0.12^{d}$ & $0 \cdot 12^{\mathrm{c}, \mathrm{d}}$ & $0 \cdot 11^{\mathrm{b}, \mathrm{c}, \mathrm{d}}$ & 0.00 & NS & 0.001 & - \\
\hline $18: 4 n-3$ & $0.45^{\mathrm{a}}$ & 0.00 & $0.98^{\mathrm{b}}$ & $0.91^{\mathrm{b}}$ & $0.86^{b}$ & $0.44^{\mathrm{a}}$ & 0.07 & $1.09^{b}$ & $1 \cdot 15^{\mathrm{b}}$ & $1.06^{\mathrm{b}}$ & $0.44^{\mathrm{a}}$ & 0.09 & 0.001 & 0.05 & NS \\
\hline $20: 0$ & $0.06^{a}$ & 0.02 & $0 \cdot 18^{b, c}$ & $0 \cdot 18^{b, c}$ & $0.17^{\mathrm{b}}$ & $0.17^{\mathrm{b}}$ & 0.01 & $0.23^{b, c}$ & $0.25^{\mathrm{c}}$ & $0.24^{\mathrm{C}}$ & $0.33^{\mathrm{d}}$ & 0.01 & NS & 0.001 & 0.01 \\
\hline $20: 1(n-9)+(n-7)$ & $1.85^{\mathrm{a}}$ & 0.07 & $6 \cdot 07^{\mathrm{c}}$ & $6 \cdot 11^{\mathrm{c}}$ & $5.35^{\mathrm{b}, \mathrm{c}}$ & $2.99^{\mathrm{a}}$ & 0.43 & $8.42^{d}$ & $9.04^{d}$ & $8.25^{\mathrm{d}}$ & $3 \cdot 74^{a, b}$ & 0.66 & 0.001 & 0.001 & 0.1 \\
\hline $20: 2 n-6$ & $0.20^{\mathrm{a}}$ & 0.01 & $0.57^{\mathrm{b}}$ & $0.54^{\mathrm{b}}$ & $0.51^{\mathrm{b}}$ & $0.69^{b, c}$ & 0.03 & $0.82^{\mathrm{c}}$ & $0.90^{c, d}$ & $0.86^{c}$ & $1 \cdot 12^{\mathrm{d}}$ & 0.04 & 0.01 & 0.001 & 0.05 \\
\hline $20: 3 n-3$ & $0.08^{a}$ & 0.00 & $0 \cdot 18^{\mathrm{a}, \mathrm{b}}$ & $0 \cdot 18^{a, b}$ & $0 \cdot 17^{a, b}$ & $0.22^{b, c}$ & 0.01 & $0.23^{b, c}$ & $0.25^{b, c}$ & $0.29^{b, c}$ & $0.33^{\mathrm{c}}$ & 0.02 & NS & 0.01 & NS \\
\hline $20: 3 n-6$ & $0.04^{a}$ & 0.00 & $0.09^{\mathrm{a}, \mathrm{b}}$ & $0.09^{a, b}$ & $0.09^{a, b}$ & $0 \cdot 14^{b, c}$ & 0.01 & $0.15^{b, c}$ & $0 \cdot 12^{b}$ & $0 \cdot 12^{\mathrm{b}}$ & $0.22^{c}$ & 0.01 & 0.01 & 0.01 & NS \\
\hline $20: 4 n-3$ & $0.35^{\mathrm{a}}$ & 0.02 & $0.83^{\mathrm{b}}$ & $0.82^{\mathrm{b}}$ & $0.77^{b}$ & $0.42^{\mathrm{a}}$ & 0.06 & $1 \cdot 17^{\mathrm{c}}$ & $1.23^{\mathrm{c}}$ & $1 \cdot 19^{c}$ & $0.55^{a, b}$ & 0.09 & 0.001 & 0.001 & 0.1 \\
\hline $20: 4 n-6$ & $0.12^{\mathrm{a}}$ & 0.01 & $0 \cdot 18^{a, b}$ & $0.18^{\mathrm{b}}$ & $0 \cdot 17^{\mathrm{a}, \mathrm{b}}$ & $0.17^{\mathrm{a}, \mathrm{b}}$ & 0.01 & $0.23^{\mathrm{b}}$ & $0.20^{\mathrm{b}}$ & $0.24^{\mathrm{b}}$ & $0.22^{\mathrm{b}}$ & 0.01 & NS & 0.01 & NS \\
\hline $20: 5 n-3$ (EPA) & $1 \cdot 31^{a}$ & 0.05 & $2.75^{\mathrm{b}}$ & $2 \cdot 69^{b}$ & $2.54^{\mathrm{b}}$ & $1.33^{\mathrm{a}}$ & 0.19 & $3.24^{\mathrm{b}}$ & $3.36^{\mathrm{b}}$ & $3 \cdot 10^{\mathrm{b}}$ & $1 \cdot 17^{\mathrm{a}}$ & 0.28 & 0.001 & 0.05 & 0.1 \\
\hline $21: 5 n-3$ & $0.08^{\mathrm{a}}$ & 0.00 & $0.18^{\mathrm{b}, \mathrm{c}}$ & $0.18^{b, c}$ & $0.15^{a, b}$ & $0.09^{\mathrm{a}}$ & 0.01 & $0.23^{\mathrm{c}}$ & $0.25^{\mathrm{c}}$ & $0.24^{c}$ & - & 0.00 & 0.05 & 0.001 & NS \\
\hline $22: 0$ & - & - & $0.09^{\mathrm{a}}$ & $0.09^{\mathrm{a}}$ & $0.09^{a}$ & $0.08^{\mathrm{a}}$ & 0.00 & $0.12^{b}$ & $0.12^{\mathrm{b}}$ & $0 \cdot 12^{\mathrm{b}}$ & $0.11^{b}$ & 0.00 & NS & 0.001 & - \\
\hline $22: 1(n-11)+(n-9)+(n-7)$ & $1.99^{a}$ & 0.10 & $6 \cdot 34^{\mathrm{b}}$ & $6 \cdot 38^{b, c}$ & $5.57^{b, c}$ & $2 \cdot 30^{\mathrm{a}}$ & 0.54 & $8 \cdot 30^{c, d}$ & $9.01^{d}$ & $8 \cdot 14^{c, d}$ & $2 \cdot 22^{\mathrm{a}}$ & 0.84 & 0.001 & 0.001 & 0.05 \\
\hline $22: 5 n-3$ & $0.55^{\mathrm{a}}$ & 0.03 & $1.06^{\mathrm{b}}$ & $1.09^{\mathrm{b}, \mathrm{c}}$ & $1.00^{\mathrm{b}}$ & $0.55^{\mathrm{a}}$ & 0.07 & $1.37^{b, c}$ & $1.48^{\mathrm{C}}$ & $1.39^{b, c}$ & $0.51^{\mathrm{a}}$ & 0.12 & 0.001 & 0.01 & - \\
\hline $22: 6 n-3(\mathrm{DHA})$ & $5.97^{a}$ & 0.02 & $8.98^{\mathrm{b}}$ & $9 \cdot 26^{b, c}$ & $9.68^{b, c}$ & $9.93^{b, c}$ & 0.29 & $9 \cdot 25^{b, c}$ & $10 \cdot 27^{b, c}$ & $12 \cdot 20^{\mathrm{d}}$ & $11 \cdot 78^{\mathrm{c}, \mathrm{d}}$ & 0.40 & 0.05 & 0.01 & 0.01 \\
\hline $24: 1 n-9$ & $0.21^{a}$ & 0.01 & $0.44^{b, c, d}$ & $0.45^{\mathrm{c}, \mathrm{d}}$ & $0.40^{\mathrm{b}, \mathrm{c}}$ & $0.25^{\mathrm{a}}$ & 0.03 & $0.47^{c, d}$ & $0.53^{\mathrm{d}}$ & $0.49^{c, d}$ & $0.33^{a, b}$ & 0.02 & 0.001 & 0.01 & NS \\
\hline Sum SFA & $7.51^{a}$ & 0.11 & $16 \cdot 14^{\mathrm{b}, \mathrm{c}}$ & $16 \cdot 29^{\mathrm{b}, \mathrm{c}}$ & $16 \cdot 29^{b, c}$ & $15 \cdot 74^{\mathrm{b}}$ & 0.52 & $21 \cdot 14^{\mathrm{b}, \mathrm{c}, \mathrm{d}}$ & $22 \cdot 30^{d}$ & $23.67^{d}$ & $21.54^{\mathrm{c}, \mathrm{d}}$ & 0.56 & NS & 0.001 & NS \\
\hline Sum MUFA & $14.39^{\mathrm{a}}$ & 0.41 & $39 \cdot 37^{\mathrm{b}}$ & $39.49^{\mathrm{b}}$ & $36 \cdot 50^{\mathrm{b}}$ & $33 \cdot 21^{b}$ & 1.48 & $54.20^{\mathrm{c}}$ & $56.85^{\mathrm{c}}$ & $55.42^{\mathrm{c}}$ & $46.62^{\mathrm{b}, \mathrm{c}}$ & 1.62 & NS & 0.001 & NS \\
\hline Total PUFA & $12 \cdot 30^{\mathrm{a}}$ & 0.20 & $24.84^{b}$ & $25 \cdot 13^{\mathrm{b}, \mathrm{c}}$ & $24.84^{\mathrm{b}, \mathrm{c}}$ & $24.65^{b}$ & 0.78 & $30 \cdot 01^{b, c}$ & $32.05^{\mathrm{b}, \mathrm{c}}$ & $33.98^{\mathrm{C}}$ & $31 \cdot 71^{b, c}$ & 0.73 & NS & 0.001 & NS \\
\hline Sum $n-3$ PUFA & $9 \cdot 61^{\mathrm{a}}$ & $0 \cdot 10$ & $17.03^{\mathrm{b}, \mathrm{c}}$ & $17 \cdot 27^{\mathrm{b}, \mathrm{c}}$ & $17 \cdot 29^{b, c}$ & $15 \cdot 45^{\mathrm{b}}$ & 0.56 & $19 \cdot 35^{b, c, d}$ & $20 \cdot 87^{c, d}$ & $22.50^{d}$ & $18 \cdot 32^{b, c, d}$ & 0.61 & NS & 0.01 & NS \\
\hline Sum $n-6$ PUFA & $2.57^{a}$ & 0.09 & $7.53^{\mathrm{b}}$ & $7.59^{\mathrm{b}, \mathrm{c}}$ & $7 \cdot 30^{\mathrm{b}}$ & $9.06^{b, c, d}$ & 0.33 & $10 \cdot 28^{c, d}$ & $10 \cdot 80^{\mathrm{d}, \mathrm{e}}$ & $11 \cdot 11^{\mathrm{d}, \mathrm{e}}$ & $13 \cdot 27^{\mathrm{e}}$ & 0.40 & 0.01 & 0.001 & NS \\
\hline Sum fatty acids & $34 \cdot 21^{a}$ & 0.72 & $80 \cdot 35^{\mathrm{b}, \mathrm{c}}$ & $80.90^{\mathrm{b}, \mathrm{c}}$ & $77.63^{\mathrm{b}}$ & $73 \cdot 61^{b}$ & 2.69 & $105 \cdot 35^{c}$ & $111 \cdot 20^{\mathrm{d}}$ & $113.07^{d}$ & $99.87^{\mathrm{b}, \mathrm{c}, \mathrm{d}}$ & 2.67 & NS & 0.001 & 0.05 \\
\hline $\mathrm{EPA}+\mathrm{DHA}$ & $7 \cdot 28^{\mathrm{a}}$ & 0.23 & $11.73^{\mathrm{b}}$ & $11.95^{\mathrm{b}, \mathrm{c}}$ & $12 \cdot 22^{b, c}$ & $11 \cdot 25^{b}$ & 0.36 & $12 \cdot 49^{\mathrm{b}, \mathrm{c}}$ & $13.63^{\mathrm{b}, \mathrm{c}}$ & $15 \cdot 30^{c}$ & $12 \cdot 95^{\mathrm{b}, \mathrm{c}}$ & 0.40 & NS & 0.01 & 0.001 \\
\hline
\end{tabular}

0_ScYE, $0 \mathrm{~g} / \mathrm{kg}$ Scizochytrium sp. + yeast extract (control); 1_ScYE, $10 \mathrm{~g} / \mathrm{kg}$ Scizochytrium sp. + yeast extract; 6_ScYE, $60 \mathrm{~g} / \mathrm{kg}$ Scizochytrium sp. + yeast extract; $15 \_S c Y E, 150 \mathrm{~g} / \mathrm{kg}$ Scizochytrium sp. + yeast extract.

${ }^{a-e}$ Mean values within a row with unlike superscript letters were significantly different $(P<0.05$; one-way ANOVA as separated by Tukey's post hoc test). Post hoc tests were not performed when groups had fewer than two cases.

* Heterotrophically produced Scizochytrium sp., spray dried and balanced to $500 \mathrm{~g} / \mathrm{kg}$ total fat by yeast extract (Alltech Inc.).

† 0_ScYE: 153/0; 1_ScYE: 148.5/10; 6_ScYE: 122.4/60; 15_ScYE: 0/150 g/kg supplemental dietary fish oil/ScYE, respectively. 
Table 6. Experimental diets' crude protein, crude lipid, energy and fatty acid percentage apparent digestibility coefficient (\% ADC) in Atlantic salmon (Salmo salar)

(Mean values with their standard errors)

\begin{tabular}{|c|c|c|c|c|c|}
\hline Diet. .. & 0_ScYE & 1_ScYE & 6_ScYE & 15_ScYE & $\operatorname{SEM}(n 12)$ \\
\hline Supplemental dietary fish oil ( $\mathrm{g} / \mathrm{kg}$ diet) & 153.0 & 148.5 & $122 \cdot 4$ & 0 & \\
\hline Dietary ScYE* (g/kg diet) & 0 & 10 & 60 & 150 & \\
\hline $\mathrm{ADC}_{\text {protein }}$ & $87 \cdot 7$ & $87 \cdot 6$ & $87 \cdot 1$ & $87 \cdot 1$ & 0.1 \\
\hline ADC lipid & $95 \cdot 8^{\mathrm{c}}$ & $96 \cdot 0^{\mathrm{C}}$ & $93.9^{\mathrm{b}}$ & $87 \cdot 8^{a}$ & 1.0 \\
\hline ADC energy & $83 \cdot 2^{b}$ & $84 \cdot 2^{c}$ & $83 \cdot 4^{b}$ & $79 \cdot 7^{\mathrm{a}}$ & 0.5 \\
\hline ADC14:0 & $97 \cdot 2^{\mathrm{C}}$ & $97 \cdot 2^{\mathrm{C}}$ & $92.9^{b}$ & $69 \cdot 0^{\mathrm{a}}$ & 3.5 \\
\hline ADC16:0 & $95 \cdot 8^{c}$ & $94.4^{c}$ & $83 \cdot 1^{b}$ & $64 \cdot 8^{\mathrm{a}}$ & 3.7 \\
\hline ADC $18: 0$ & $95 \cdot 8^{\mathrm{c}}$ & $95 \cdot 7^{\mathrm{c}}$ & $93 \cdot 2^{b}$ & $84 \cdot 7^{\mathrm{a}}$ & 1.4 \\
\hline ADC $20: 0$ & $95 \cdot 8^{\mathrm{C}}$ & $96 \cdot 0^{\mathrm{c}}$ & $93.9^{b}$ & $90 \cdot 8^{\mathrm{a}}$ & 0.6 \\
\hline ADC $22: 0$ & $91 \cdot 7^{\mathrm{b}}$ & $92.0^{\mathrm{b}}$ & $87 \cdot 7^{\mathrm{a}}$ & $87.8^{a}$ & 0.6 \\
\hline ADC $16: 1 n-7$ & $99 \cdot 3^{\mathrm{b}}$ & $99 \cdot 4^{\mathrm{b}}$ & $99 \cdot 3^{\mathrm{b}}$ & $98 \cdot 3^{\mathrm{a}}$ & 0.1 \\
\hline ADC $18: 1(n-9)+(n-7)+(n-5)$ & $99 \cdot 1$ & $99 \cdot 3$ & $99 \cdot 3$ & $99 \cdot 3$ & 0.0 \\
\hline ADC $20: 1(n-9)+(n-7)$ & $98 \cdot 3$ & 98.7 & 98.8 & 98.4 & 0.1 \\
\hline ADC $22: 1(n-11)+(n-9)+(n-7)$ & 97.9 & 98.4 & 98.5 & 98.3 & 0.1 \\
\hline ADC $24: 1 n-9$ & 93.8 & $95 \cdot 0$ & 93.9 & - & 0.2 \\
\hline ADC $16: 2 n-4$ & 100 & 100 & 100 & - & 0.0 \\
\hline ADC $16: 3 n-4$ & 100 & 100 & 100 & - & 0.0 \\
\hline ADC $18: 2 n-6$ & $98 \cdot 8$ & 99.0 & 99.0 & 98.9 & 0.0 \\
\hline ADC $20: 2 n-6$ & 98.6 & 100 & 100 & - & 0.4 \\
\hline ADC $20: 4 n-6$ & $99 \cdot 3$ & 100 & 100 & - & 0.2 \\
\hline ADC $18: 3 n-3$ & 99.4 & 99.6 & 99.6 & 99.6 & 0.0 \\
\hline ADC $18: 4 n-3$ & 99.8 & 99.9 & 100 & 100 & 0.0 \\
\hline ADC $20: 3 n-3$ & 100 & - & 100 & - & 0.0 \\
\hline ADC $20: 4 n-3$ & 99.7 & 99.7 & 100 & 100 & 0.1 \\
\hline ADC $20: 5 n-3$ & 99.5 & 99.6 & 99.6 & 99.3 & 0.1 \\
\hline ADC $21: 5 n-3$ & 100 & 100 & 98.9 & - & 0.3 \\
\hline ADC $22: 5 n-3$ & 98.9 & 99.5 & 98.9 & 100 & 0.2 \\
\hline ADC $22: 6 n-3$ & $99.0^{b}$ & $99 \cdot 1^{b}$ & $99 \cdot 1^{b}$ & $98 \cdot 1^{\mathrm{a}}$ & 0.1 \\
\hline ADC of total SFA & $96 \cdot 1^{\mathrm{c}}$ & $95 \cdot 1^{\mathrm{c}}$ & $86 \cdot 0^{\mathrm{b}}$ & $67 \cdot 0^{\mathrm{a}}$ & 3.5 \\
\hline ADC of total MUFA & $98 \cdot 7^{\mathrm{a}}$ & $99.0^{b}$ & $99.1^{\mathrm{b}}$ & $99 \cdot 2^{b}$ & 0.1 \\
\hline ADC of total PUFA $(n-6)$ & 98.8 & 99.0 & $99 \cdot 1$ & 98.9 & 0.1 \\
\hline ADC of total PUFA $(n-3)$ & $99 \cdot 3^{b}$ & $99 \cdot 4^{b}$ & $99 \cdot 4^{b}$ & $98.6^{a}$ & 0.1 \\
\hline ADC of total PUFA & $99 \cdot 2^{\mathrm{b}}$ & $99 \cdot 3^{\mathrm{b}}$ & $99 \cdot 3^{\mathrm{b}}$ & $98 \cdot 7^{\mathrm{a}}$ & 0.1 \\
\hline ADC of total fatty acids & $98 \cdot 4^{\mathrm{c}}$ & $98 \cdot 3^{\mathrm{C}}$ & $96 \cdot 2^{b}$ & $90 \cdot 2^{\mathrm{a}}$ & 1.0 \\
\hline
\end{tabular}

0_ScYE, $0 \mathrm{~g} / \mathrm{kg}$ Scizochytrium sp. + yeast extract (control); 1_ScYE, $10 \mathrm{~g} / \mathrm{kg}$ Scizochytrium sp. + yeast extract; 6_ScYE, 60 g/kg Scizochytrium sp. + yeast extract; 15_ScYE, $150 \mathrm{~g} / \mathrm{kg}$ Scizochytrium sp. + yeast extract.

a,b,c Mean values within a row with unlike superscript letters were significantly different $(P<0.05$; one-way ANOVA as separated by Tukey's post hoc test).

${ }^{*}$ Heterotrophically produced Scizochytrium sp., spray dried and balanced to $500 \mathrm{~g} / \mathrm{kg}$ total fat by yeast extract (Alltech Inc.).

the control fish, no iNOS was detected in this part of the intestine (not shown). Moreover, increased iNOS activity and more goblet cells were evident in the villi from fish fed $6 \% \mathrm{ScYE}$ in the diet (Fig. 2(D): arrow). Dietary inclusion of $15 \%$ ScYE showed similar iNOS activity as for $6 \%$ at the base of the intestine (Fig. 2(E): arrow head). In the villi a considerable increase in mucus, goblet cell number (Fig. 2(F): arrow) and iNOS activity was evident when $15 \%$ ScYE was included in the diet (Fig. 2(F): arrow head). The plasma CK level showed no significant differences between the dietary treatments, but the plasma CK value in salmon from one of the tanks fed the 15_ScYE diet was severely elevated (246 220 U/l) compared with the average level. Hence, CK seems to a parameter that might be valuable to monitor in future studies.

\section{Discussion}

Atlantic salmon performance in the present trial fed either fish oil or microalgae (ScYE) as an $n$-3 LC-PUFA supplement in the diet was optimal in all treatments as compared with previously reported trials using similar diets to the control of the present trial and similar fish sizes ${ }^{(62,63)}$ or other diets containing Schirochytrium sp. oil ${ }^{(64)}$. Fish in the 1_ScYE treatment with the highest postprandial blood plasma leptin levels than all treatments also had the highest growth, significantly when compared with fish in 15_ScYE, whereas the opposite may have been expected in a group with high feed intake rates and energy status. Except for 1_ScYE, among the fish in the other treatments postprandial plasma leptin correlated negatively with growth rather than feed intake, whereas in all treatments feed intake was positively correlating with FCR and not growth. This provides an indication that postprandial leptin blood plasma levels may reflect the growth status or potential of the fish fed diets with different levels of digestible lipid and energy ${ }^{(65,66)}$. Sissener et al. ${ }^{(67)}$ found no increase in leptin gene expression in fish fed high-plant protein and highplant oil diets. Accordingly in our trial there was no difference in plasma leptin level of fish fed diet 15_ScYE which contained no fish oil and higher levels of rapeseed oil compared with the control and diet 6_ScYE.

In terms of dietary nutrient digestibility in salmon, the observed significant reduction in total lipid and gross energy 

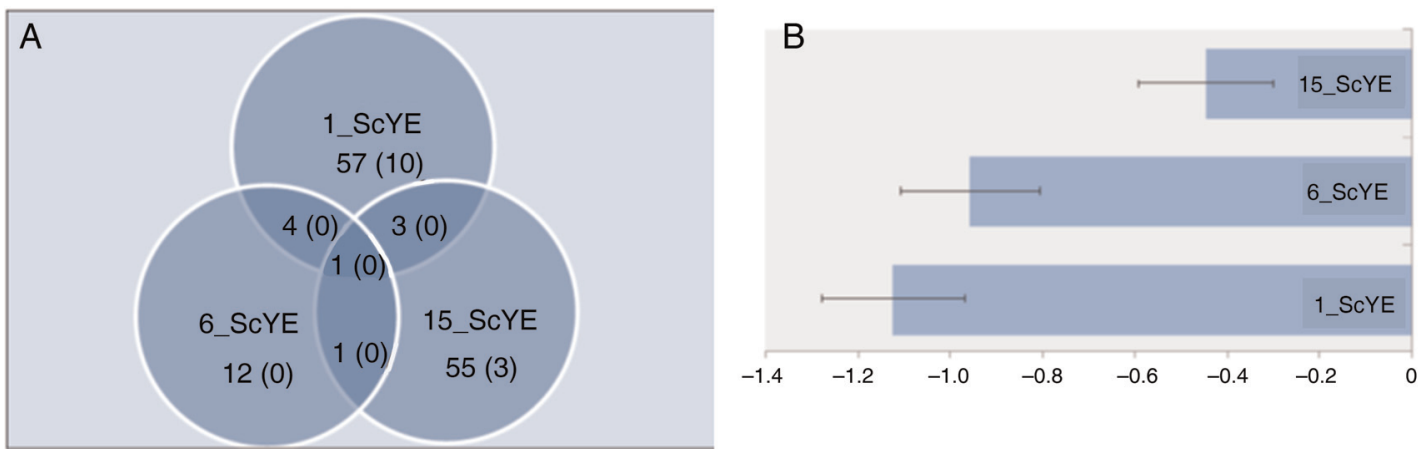

Fig. 1. Microarray analyses in the liver of Atlantic salmon (Salmo salar) fed diets with graded ScYE (heterotrophically produced Scizochytrium sp., spray dried and balanced to $500 \mathrm{~g} / \mathrm{kg}$ total fat by yeast extract) level $(0,1,6$ and $15 \%)$. (A) The numbers of differentially expressed genes detected with microarrays. Genes were

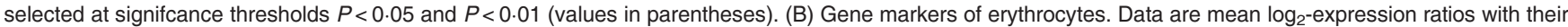
standard errors for twelve genes: carbonic anhydrase, ammonium transporter RhB, erythroid-specific 5-aminolevulinate synthase (three features), haemoglobins (seven features).

$\mathrm{ADC}$ at the two highest dietary ScYE supplementation levels can be explained by the lower digestibility of the dietary SFA. This can be due to the limited capacity of Atlantic salmon to efficiently digest SFA at low temperatures and increasing dietary levels, as already reported by other studies ${ }^{(68,69)}$. Menoyo et al. ${ }^{(69)}$ found that fish oil SFA digestibility in salmon decreases at dietary levels above $13.5 \%$ down to ADC values of $78 \%$ at $32 \%$ SFA levels in the dietary oil. 16:0 is the main SFA both in fish oil and ScYE showing decreasing ADC when fed to salmon at dietary levels above $10 \%$. SFA digestibility may also be affected by the positioning of the SFA in the microalgal TAG as previously suggested by $\mathrm{Bracco}^{(70)}$. Most fatty acids in ScYE are present in the form of TAG, the composition of which is currently unknown. Another hypothesis explaining reduced digestibility of microalgae nutrients is the integrity of cell walls, which may not be efficiently disrupted during

Table 7. Examples of differentially expressed genes (microarray analyses) in the liver of Atlantic salmon (Salmo salar) fed diets with graded ScYE† inclusion levels $(1,6$ and $15 \%) \ddagger$

\begin{tabular}{|c|c|c|c|c|}
\hline Gene & Function & 1_ScYE & 6_ScYE & 15_ScYE \\
\hline p53 & Cell cycle, apoptosis & $2 \cdot 0$ & $3.5^{\star}$ & $2 \cdot 5^{*}$ \\
\hline Myristoylated alanine-rich C kinase-like protein & Cell cytoskeleton & $-1.5^{\star}$ & -1.4 & $-2 \cdot 1^{*}$ \\
\hline Keratin, type I cytoskeletal $50 \mathrm{kDa}$ & Cell cytoskeleton & $3.5^{\star}$ & 3.3 & $2 \cdot 7$ \\
\hline Centrosome-associated protein CEP250 & Cell cytoskeleton & $-2 \cdot 7^{*}$ & $-1 \cdot 9^{*}$ & $-1 \cdot 1$ \\
\hline SH3 domain-binding glutamic acid-rich-like protein 3 & Cell redox & $-1 \cdot 1$ & -1.9 & $-2 \cdot 6^{*}$ \\
\hline RNA binding motif protein 12 & Cell RNA & $1 \cdot 8$ & 1.6 & $3 \cdot 6^{*}$ \\
\hline Synaptic vesicle 2-related protein & Cell secretion & $2 \cdot 4^{*}$ & 1.0 & $2 \cdot 2$ \\
\hline Rap guanine exchange factor & Cell signalling & $2 \cdot 7^{*}$ & 1.9 & $2 \cdot 1$ \\
\hline cGMP 3,5-cyclic phosphodiesterase subunit $\delta$ & Cell signalling & 1.7 & 1.0 & $2 \cdot 0^{*}$ \\
\hline Small ubiquitin-related modifier 2 precursor & Cell signalling & $-1 \cdot 7^{\star}$ & $-2 \cdot 1$ & $-1 \cdot 8^{*}$ \\
\hline Sestrin & Cell stress & $-5 \cdot 3$ & $-3 \cdot 0^{*}$ & -1.9 \\
\hline Diencephalon/mesencephalon homeobox protein 1-A & Cell transcription & $1.8^{*}$ & $2 \cdot 2$ & 1.5 \\
\hline Helicase-like transcription factor & Cell transcription & $-1.9^{\star}$ & $-1 \cdot 7^{\star}$ & $-2 \cdot 3$ \\
\hline Pancreatic progenitor cell differentiation and proliferation factor & Differentiation & $1 \cdot 1$ & 1.7 & $2 \cdot 1^{*}$ \\
\hline Urokinase-type plasminogen activator & Extracellular & $1 \cdot 0$ & $-1 \cdot 8$ & $-2 \cdot 3^{*}$ \\
\hline Collagen $6 \mathrm{A3}$ & Extracellular & -1.9 & $-1 \cdot 7$ & $-2 \cdot 5^{\star}$ \\
\hline Complement factor $\mathrm{H} 1$ & Immune complement & $-1 \cdot 8^{*}$ & -1.4 & $-1 \cdot 6^{\star}$ \\
\hline IL-16 & Immune cytokine & $-2 \cdot 2$ & $1 \cdot 0$ & $-1 \cdot 8^{*}$ \\
\hline Lectin precursor & Immune lectin & $-3 \cdot 6^{\star}$ & $-2 \cdot 4^{*}$ & -1.4 \\
\hline Glutamyl-tRNA(GIn) amidotransferase A, mitochondrial & Metabolism amino acids & $-2 \cdot 9^{*}$ & -1.6 & $-2 \cdot 2$ \\
\hline L-Asparaginase & Metabolism amino acids & $1 \cdot 7^{\star}$ & $2 \cdot 8^{\star}$ & $2 \cdot 8^{*}$ \\
\hline Multiple inositol polyphosphate histidine phosphatase 1 & Metabolism inositol & $-1 \cdot 8^{\star}$ & -1.1 & $-2 \cdot 2^{*}$ \\
\hline Sodium/potassium/calcium exchanger & Metabolism ion & $-1 \cdot 3^{*}$ & $-2 \cdot 3^{*}$ & $-2 \cdot 0^{*}$ \\
\hline Chloride intracellular channel protein 2 & Metabolism ion & $-2 \cdot 1^{*}$ & $-1.5^{\star}$ & -1.8 \\
\hline Malonyl-CoA decarboxylase, mitochondrial & Metabolism lipid & $-1.9^{*}$ & $-1 \cdot 8$ & $-1 \cdot 8^{*}$ \\
\hline Thymus-specific serine protease & Metabolism protease & $-2 \cdot 3^{*}$ & -1.8 & -1.3 \\
\hline ATP-binding cassette G2 & Metabolism xenobiotic & $-2 \cdot 0^{*}$ & $-1.5^{\star}$ & -1.8 \\
\hline NACHT domain containing & Unknown & $2 \cdot 3^{*}$ & $1.9^{\star}$ & $2 \cdot 1^{*}$ \\
\hline
\end{tabular}

1_ScYE, $10 \mathrm{~g} / \mathrm{kg}$ Scizochytrium sp. + yeast extract; 6_ScYE, $60 \mathrm{~g} / \mathrm{kg}$ Scizochytrium sp. + yeast extract; $15 \_S c Y E, 150 \mathrm{~g} / \mathrm{kg}$ Scizochytrium sp. + yeast extract; 0_ScYE, 0 g/kg Scizochytrium sp. + yeast extract (control); NACHT, NAIP (neuronal apoptosis inhibitory protein), CIITA (MHC class II transcription activator), HET-E (incompatibility locus protein from Podospora anserina) and TP1 (telomerase-associated protein).

* Significantly different values $(P<0.05)$.

† Heterotrophically produced Scizochytrium sp., spray dried and balanced to $500 \mathrm{~g} / \mathrm{kg}$ total fat by yeast extract (Alltech Inc.).

‡ Data are fold changes compared with the control treatment (0_ScYE). 

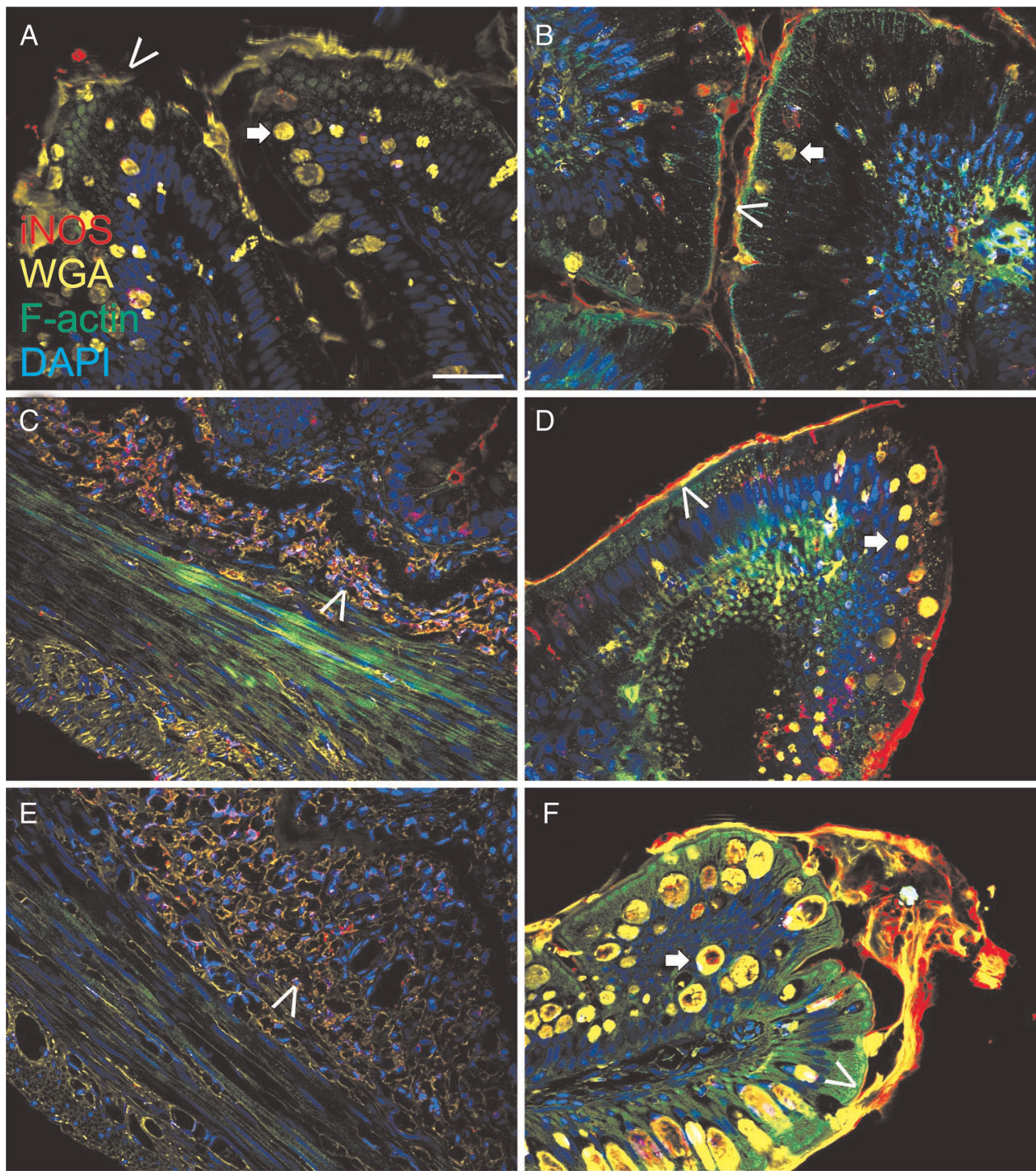

Fig. 2. Immunofluorescence analysis of inducible nitric oxide synthase (iNOS) activity (pseudocoloured red) and fluorescence stainiong of F-actin (pseudocoloured green) and goblet cells (pseudocoloured yellow) in Atlantic salmon (Salmo salar) intestines fed variable levels of ScYE (heterotrophically produced Scizochytrium sp., spray dried and balanced to $500 \mathrm{~g} / \mathrm{kg}$ total fat by yeast extract). Nuclei were stained with DAPI (4',6-diamidino-2-phenylindole; pseudocoloured blue). (A) The control fish showed normal intestinal morphology and a low iNOS activity. Distribution and number of goblet cells (arrow) and apical F-actin (arrow head) in the enterocytes appeared normal. (B) Intestines from fish fed a diet with $1 \%$ ScYE showed a normal morphology with respect to the number of goblet cells (arrow) and apical F-actin (arrow head), but slightly more intense apical iNOS activity in the enterocytes. (C) In fish fed $6 \%$ ScYE we observed an increased iNOS activity in the submucosa (arrow head). (D) In the villus of fish fed $6 \%$ ScYE apical iNOS was more intense (arrow head) and some enterocytes and goblet cells also showed increased iNOS staining. (E) Inclusion levels of $15 \%$ ScYE revealed similar iNOS activity in the submucosa (arrow head), but the villus (F) appeared quite different from the control fish with increased number of swollen goblet cells (arrow), more intense F-actin staining (arrow head) and higher iNOS activity. White bar in Fig. 2(A) =20 $\mu \mathrm{m}$. WGA, wheat germ agglutinin.

processing and feed production or during digestion in the organism's intestinal tract. Nevertheless, following the fatty acid ADC results of the present study, showing very high PUFA and at the same time low SFA digestibility in the ScYE supplemented diets, this hypothesis seems improbable. The present results thus suggest that the extrusion method used to produce the algae-containing feeds is adequate processing for optimal cell wall disruption of these algae.

Though intestinal morphology of Atlantic salmon fed increasing levels of ScYE was unaffected, ScYE apparently led to innate immune responses, such as increased mucus production and number of Goblet cells, as recently also reported in other farmed fish species fed different microalgae products in the diet ${ }^{(40,41)}$. The innate immune system of fish is highly advanced $^{(71)}$ and in some respects may be superior to the mammalian ${ }^{(72,73)}$, providing higher responses to induced stimuli. It is well known that mucus is an important physical barrier against intestinal bacteria; hence, our observations could point towards an improved gut health by dietary ScYE supplementation. However, increased mucus production is also observed as a response to intestinal irritation. Recently, Schreiber et al. ${ }^{(74)}$ showed that iNOS controls baseline mucus production and that disruption of the intestinal mucus layer due to inflammatory diseases such as bowel or Crohn's disease are followed by increased iNOs activity and mucus production. The observed intestinal activity of mucus and iNOS activity indicate that ScYE may affect intestinal health. However, we did not observe signs of enteritis even after 12 weeks and the growth 
performance of the fish suggests that the currently tested inclusion levels are acceptable to the fish.

The DHA incorporation in the salmon fillet of the present study was effective also in the absence of supplemental dietary fish oil in treatment 15_ScYE. According to the Global Organization for EPA and DHA Omega-3 (GOED), the consumer needs to be informed of the beneficial effects obtained with a daily DHA intake of $250 \mathrm{mg}$ or $1.75 \mathrm{~g}$ per week. These levels of DHA intake can be met by eating approximately one portion of salmon $(125 \mathrm{~g})$ from the present experiments per week, namely $140 \mathrm{~g}$ fish fillet of the control, or $129 \mathrm{~g}$ fish fillet of the 0_ScYE, or $114 \mathrm{~g}$ fish fillet of the 6_ScYE, or $136 \mathrm{~g}$ fish fillet of the 15_ScYE treatment. Xu et al. ${ }^{(75)}$ found recently that $\Delta 6$ fatty acyl desaturase (FADS2) activity gene expression as well as the tissue levels of LC $n$-3 highly unsaturated fatty acids (HUFA) in the Japanese sea bass (Lateolabrax japonicus) were higher in fish fed palmitic acid-rich diets, in the form of tripalmitin, TAG:(16:0/16:0/16:0), compared with diets rich in either one of LC $n$-3 HUFA, stearic, oleic and $\alpha$-linolenic acid. In the present study, the fish fillets of salmon fed diet 15_ScYE, containing the highest amounts of $16: 0$, no supplemental fish oil and low EPA levels, maintained the original levels of EPA. Though no mass balance analyses were performed, this fact indicates that farmed salmon smolt may efficiently preserve EPA in the tissues when this is not provided in excess by the $\operatorname{diet}^{(76)}$. This can be due to reduced $\beta$-oxidation of EPA and increased desaturation and elongation of shorter-chain fatty acids provided by the dietary plant oils or even by retroconversion of the algal DHA to EPA. The fish at the end of the feeding trial were 4-5 times smaller than market-size fish when total fillet lipids are expected to be more than double than in the present study ${ }^{(77)}$ and so are expected to be the total amounts of DHA and total $n-3$ LC-PUFA. Thus, in terms of health and market standards, the experimental diets were well on the safe side of $n$ - 3 LC-PUFA levels, and in practice lower levels of algae biomass will be required in aqua feeds, allowing for lower feed cost formulations.

Liquid losses during storage are currently an issue in certain salmon fillet products, probably caused by the high level of unsaturated fatty acids present in the alternative plant oil sources used in fish feeds, such as rapeseed oil, causing both technical problems and nutrient wastage. In our trial, the fillet quality was equally good in all treatments in terms of gaping, texture and liquid losses during thawing despite the high rapeseed oil levels present in the 15_ScYE treatment. This may be explained by the maintenance of similar or higher levels of SFA in the fillet of the fish fed the ScYE-supplemented diets compared with the control, as ScYE is very rich in SFA and balances the very low saturation profile of supplemental rapeseed oil.

High-throughput gene expression profiling was performed to assess potential adverse dietary effects of microalgae. The microarray platform provides comprehensive coverage of diverse pathways and functional groups (online Supplementary Table S2) and taking into account results produced by our team in diverse studies, any signs of stress, toxicity, inflammation and other damage would be seen without a doubt. Overall, gene expression changes were small, being close to the margin of detectability, as also previously observed in gilthead sea bream fed microalgae in the diet ${ }^{(78)}$. We did not find enrichment of any pathway or functional category except for the markers of erythrocytes that showed slight reduction at the lowest level of algae. In the present study, we found only one regulated group including seventeen functionally related genes involved in overall oxygen transport and more specifically metabolism and transport of $\mathrm{Fe}$ and haeme (Table 7). Lower abundance of transcripts for 5-aminolevulinate synthase, the key enzyme of haeme biosynthesis, globins and Rhesus blood group-associated glycoprotein could imply that livers from salmon fed with test diets contained fewer erythrocytes. At the same time, the extracellular Fe transporter (transferrin) and the key endocrine regulator of $\mathrm{Fe}$ metabolism (hepcidin) were up-regulated with increasing levels of algae component, while the intracellular Fe storage protein (ferritin) showed the opposite regulation. The gene expression profiles most probably reflect a slight reduction in either blood circulation or erythropoiesis. However, this apparently had a minor impact on the fish. There were no signs of toxicity, stress, inflammation or any other negative effects from feeds with algae. Concerning lipid metabolism, only one enzyme (acylCoA synthetase long-chain family member 4a) showed higher expression in the 1_ScYE group. Together with minor overlap between the study groups, the observed expression changes most probably were sporadic in character. Several genes can be of interest if their differential expression is confirmed in further studies. To conclude, the microarray data support safety of the ScYE product for Atlantic salmon.

Overall, it is evident from the results of this trial that whole Schizochytrium sp.-based microalgae raw materials can provide both a good alternative to the depleting marine resources of $n$-3 LC-PUFA, and a realistic one, as this species can be produced efficiently using advanced fermentation technology in all parts of the world.

\section{Supplementary material}

To view supplementary material for this article, please visit http://dx.doi.org/10.1017/jns.2015.14

\section{Acknowledgements}

The authors further acknowledge the significant contributions of Nofima's employees at The Feed Technology Center for the production of the experimental feeds, at the Research station at Sunndalsøra for a well-run fish feeding trial and at BioLab for the realisation of chemical analyses in fish, feeds and raw materials.

The experimental works undertaken through the AlltechNofima Strategic Research Alliance were realised by the supply of products and full financial support from Alltech Inc.

All the authors were involved directly in all aspects of the present study and article preparation, that is, the formulation of the research questions, designing and carrying out the technical, chemical and biological studies, analysing the data and writing parts of the article.

There are no conflicts of interest. 


\section{References}

1. Ruxton CHS, Reed SC, Simpson MJA, et al. (2007) The health benefits of omega-3 polyunsaturated fatty acids: a review of the evidence. J Hum Nutr Diet 20, 275-285.

2. Mozaffarian D, Lemaitre RN, King IB, et al. (2013) Plasma phospholipid long-chain omega-3 fatty acids and total and causespecific mortality in older adults: a cohort study. Ann Intern Med $158,515-525$.

3. Zhang J, Sasaki S, Amano K, et al. (1999) Fish consumption and mortality from all causes, ischemic heart disease, and stroke: an ecological study. Prev Med 28, 520-529.

4. Mori TA, Watts GF, Burke V, et al. (2000) Differential effects of eicosapentaenoic acid and docosahexaenoic acid on vascular reactivity of the forearm microcirculation in hyperlipidemic, overweight men. Circulation 102, 1264-1269.

5. Grimsgaard S, Bonaa KH, Hansen JB, et al. (1997) Highly purified eicosapentaenoic acid and docosahexaenoic acid in humans have similar triacylglycerol-lowering effects but divergent effects on serum fatty acids. Am J Clin Nutr 66, 649-659.

6. Pepe S \& McLennan PL (1996) Dietary fish oil confers direct antiarrhythmic properties on the myocardium of rats. J Nutr 126, 34-42.

7. Mori TA, Beilin LJ, Burke V, et al. (1997) Interactions between dietary fat, fish, and fish oils and their effects on platelet function in men at risk of cardiovascular disease. Arterioscl Throm Vas 17, 279-286.

8. Nomikos T, Karantonis HC, Skarvelis C, et al. (2006) Antiatherogenic properties of lipid fractions of raw and fried fish. Food Chem 96, 29-35.

9. Uauy R, Mena P \& Valenzuela A (1999) Essential fatty acids as determinants of lipid requirements in infants, children and adults. Eur J Clin Nutr 53, Suppl. 1, S66-S77.

10. Rennie KL, Hughes J, Lang R, et al. (2003) Nutritional management of rheumatoid arthritis: a review of the evidence. J Hum Nutr Diet 16, 97-109.

11. Nemets H, Nemets B, Apter A, et al. (2006) Omega-3 treatment of childhood depression: a controlled, double-blind pilot study. $A m \mathrm{~J}$ Psychiat 163, 1098-1100.

12. Morris MC, Evans DA, Tangney CC, et al. (2005) Fish Consumption and cognitive decline with Age in a Large Community study. Arch Neurol 62, 1849-1853.

13. Lukiw WJ \& Bazan NG (2008) Docosahexaenoic acid and the aging brain. J Nutr 138, 2510-2514.

14. Guida B, Napoleone A, Trio R, et al. (2014) Energy-restricted, $n$-3 polyunsaturated fatty acids-rich diet improves the clinical response to immuno-modulating drugs in obese patients with plaque-type psoriasis: a randomized control clinical trial. Clin Nutr 33, 399-405.

15. Souci SW, Fachmann W \& Kraut H (2008) Food Composition and Nutrition Tables. Stuttgart: MedPharm Scientific Publishers.

16. Burr ML, Fehily AM, Gilbert JF, et al. (1989) Effects of changes in fat, fish, and fibre intakes on death and myocardial reinfarction: diet and reinfarction trial (DART). Lancet ii, 757-761.

17. Stone NJ (1996) Fish consumption, fish oil, lipids, and coronary heart disease. Circulation 94, 2337-2340.

18. Mizushima S, Moriguchi EH, Ishikawa P, et al. (1997) Fish intake and cardiovascular risk among middle-aged Japanese in Japan and Brazil. I Cardiovasc Risk 4, 191-199.

19. Hu FB, Bronner L, Willett WC, et al. (2002) Fish and omega-3 fatty acid intake and risk of coronary heart disease in women. $J A M A$ 287, 1815-1821.

20. von Schacky C, Angerer P, Kothny W, et al. (1999) The effect of dietary omega-3 fatty acids on coronary atherosclerosis: a randomized, double-blind, placebo-controlled trial. Ann Intern Med 130, 554-562.

21. Pike IH \& Barlow SM (2003) Impact of fish farming on fish stocks. Fish Farmer 26, 14-16.

22. Khalilian S, Froese R, Proelss A, et al. (2010) Designed for failure: A critique of the Common Fisheries Policy of the European Union. Mar Policy 34, 1178-1182.
23. Pauly D, Christensen V, Guénette S, et al. (2002) Towards sustainability in world fisheries. Nature 418, 689-695.

24. Christensen V, Guénette S, Heymans JJ, et al. (2003) Hundred-year decline of North Atlantic predatory fishes. Fish Fish 4, 1-24.

25. Hilborn R, Branco T, Ernst B, et al. (2003) State of the world's fisheries. Annu Rev Env Res 28, 359-399.

26. Heal G \& Schlenker W (2009) Economics: sustainable fisheries. Nature 455, 1044-1045.

27. Tsikliras AC, Dinouli A \& Tsalkou E (2013) Exploitation trends of the Mediterranean and Black Sea fisheries. Acta Adriatica 54, 273-281.

28. Naylor RL, Hardy RW, Bureau DP, et al. (2009) Feeding aquaculture in an era of finite resources. Proc Natl Acad Sci U S A 106, 15103-15110.

29. Tacon AGJ \& Metian M (2008) Global overview on the use of fish meal and fish oil in industrially compounded aquafeeds: Trends and future prospects. Aquaculture 285, 146-158.

30. Jones AC, Mead A, Kaiser MJ, et al. (2014) Prioritization of knowledge needs for sustainable aquaculture: a national and global perspective. Fish Fisheries (epublication ahead of print version 4 July 2014).

31. Becker EW (2004) Microalgae in human and animal nutrition. In Handbook of Microalgal Culture: Biotechnology and Applied Phycology, pp. 312-351 [A Richmond, editor]. Oxford: Blackwell Publishing Ltd.

32. Taelman SE, De Meester S, Roef L, et al. (2013) The environmental sustainability of microalgae as feed for aquaculture: a life cycle perspective. Biores Technol 150, 513-522.

33. Muller-Feuga A (2000) The role of microalgae in aquaculture: situation and trends. I Appl Phycol 12, 527-534.

34. Patterson D \& Gatlin DM III (2013) Evaluation of whole and lipid-extracted algae meals in the diets of juvenile red drum (Sciaenops ocellatus). Aquaculture 416, 92-98.

35. Ganuza E, Benitez-Santana T, Atalah E, et al. (2008) Crypthecodinium cohnii and Schizochytrium sp as potential substitutes to fisheriesderived oils from seabream (Sparus aurata) microdiets. Aquaculture 277, 109-116.

36. Miller M, Nichols P \& Carter C (2007) Replacement of fish oil with thraustochytrid Schizochytrium sp L oil in Atlantic salmon parr (Salmo salar L) diets. Comp Biochem Physiol 148, 382-392.

37. Brown MR, Jeffery SW, Volkman JK, et al. (1997) Nutritional properties of microalgae for mariculture. Aquaculture 155, 315-331.

38. Borowitzka MA (2013) High-value products from microalgae - their development and commercialisation. J Appl Phycol 25, 743-756.

39. Markou G \& Nerantzis E (2013) Microalgae for high-value compounds and biofuels production: a review with focus on cultivation under stress conditions. Biotechnol Adv 31, 1532-1542.

40. Reyes Becerril M, Angulo C, Estrada N, et al. (2014) Dietary administration of microalgae alone or supplemented with Lactobacillus sakei affects immune response and intestinal morphology of Pacific red snapper (Lutjanus peru). Fish Shellfish Immunol 40, 208-216.

41. Reyes Becerril M, Guardiola F, Rojas M, et al. (2013) Dietary administration of microalgae Navicula sp. affects immune status and gene expression of gilthead seabream (Sparus aurata). Fish Shellfish Immunol 35, 883-889.

42. Torrecillas S, Makol A, Caballero MJ, et al. (2012) Effects on mortality and stress response in European sea bass, Dicentrarchus labrax (L.), fed mannan oligosaccharides (MOS) after Vibrio anguillarum exposure. J Fish Dis 35, 591-602.

43. Dimitroglou A, Merrifield DL, Moate R, et al. (2009) Dietary mannan oligosaccharide supplementation modulates intestinal microbial ecology and improves gut morphology of rainbow trout, Oncorbynchus mykiss (Walbaum). J Anim Sci 87, 3226-3234.

44. Jiang Y, Fan KW, Wong RT, et al. (2004) Fatty acid composition and squalene content of the marine microalga Schizochytrium mangrovei. J Agric Food Chem 52, 1196-1200.

45. Norsker NH, Barbosa MJ, Vermuëa MH, et al. (2011) Microalgal production - a close look at the economics Biotechnol Adv 29, 24-27. 
46. Suárez JA, Gaxiola G, Mendoza R, et al. (2009) Substitution of fishmeal with plant protein sources and energy Budget for white shrimp Litopenaeus vannamei (Boone, 1931). Aquaculture 289, 118-123.

47. Cabral EM, Bacelar M, Batista S, et al. (2011) Replacement of fishmeal by increasing levels of plant protein blends in diets for Senegalese sole (Solea senegalensis) juveniles. Aquaculture 322-323, 74-81.

48. Kousoulaki K, Rønnestad I, Olsen HJ, et al. (2013) Feed intake stimulation in Atlantic salmon (Salmo salar L.) by krill hydrolysate free amino acids. Aquac Nutr 19, 47-61.

49. Ren LJ, Ji XJ, Huang H, et al. (2010) Development of a stepwise aeration control strategy for efficient docosahexaenoic acid production by Schizochytrium sp. J Appl Microbiol Biotechnol 87, 1649-1656.

50. Ytrestøyl T, Aas TS, Berge GM, et al. (2011) Resource utilisation and eco-efficiency of Norwegian salmon farming in 2010. Nofima report 53/2011, p. 108. http://www.nofima.no/filearchive/ rapport-53-2011_4.pdf (accessed April 2012)

51. Bligh EG \& Dyer WJ (1959) A rapid method of total lipid extraction and purification. Can J Biochem Physiol 37, 911-917.

52. Cohen SA \& Michaud KE (1993) Synthesis of a fluorescent derivatizing reagent, 6-aminoquinolyl- $N$-hydroxysuccinimidyl carbamate, and its application for the analysis of hydrolysate amino acids via high-performance liquid chromatography. Anal Biochem 211, 279-287.

53. Tietz NW (1995) Clinical Guide to Laboratory Tests, 3rd ed. Philadelphia: W. B. Saunders.

54. Cho CY (1992) Feeding systems for rainbow trout and other salmonids with reference to current estimates of energy and protein requirements. Aquaculture 100, 107-123.

55. Mørkøre T, Hansen A $\AA$, Unander E, et al. (2002) Composition, liquid holding capacity and mechanical properties of farmed rainbow trout: variation between fillet sections and the impact of ice and frozen storage. J Food Sci 67, 1933-1938.

56. Andersen UB, Strømsnes AN, Steinsholt K, et al. (1994) Fillet gaping in farmed Atlantic salmon (Salmo salar). Norw J Agr Sci 8, 165-179.

57. Mørkøre T \& Einen O (2003) Relating sensory and instrumental texture analyses of Atlantic salmon. J Food Sci 68, 1492-1497.

58. Steedman HF (1957) Polyester wax; a new ribboning embedding medium for histology. Nature 179, 1345.

59. Ebbesson LO, Tipsmark CK, Holmqvist B, et al. (2005) Nitric oxide synthase in the gill of Atlantic salmon: colocalization with and inhibition of $\mathrm{Na}^{+}, \mathrm{K}^{+}$-ATPase. J Exp Biol 208, 1011-1017.

60. Krasnov A, Timmerhaus G, Afanasyev S, et al. (2011) Development and assessment of oligonucleotide microarrays for Atlantic salmon (Salmo salar L.). Comp Biochem Physiol Part D Genomics Proteomics 6, 31-38.

61. Laurent G, German NJ, Saha AK, et al. (2013) SIRT4 coordinates the balance between lipid synthesis and catabolism by repressing malonyl CoA decarboxylase. Mol Cell 50, 686-698.

62. Kousoulaki K, Olsen HJ, Langmyhr E, et al. (2009) Effect of fish meal water soluble fraction (stickwater) inclusion in very low fish meal diets for Atlantic salmon (Salmo salar L.) performance and body composition and fillet quality. Aquaculture 289, 74-83.
63. Kousoulaki K, Olsen HJ, Albrektsen S, et al. (2012) High growth rates in Atlantic salmon (Salmo salar L.) fed $7.5 \%$ fish meal in the diet. Micro-, ultra- and nano-filtration of stickwater and effects of different fractions and 3 compounds on pellet quality and fish performance. Aquaculture 338-341, 134-146.

64. Miller MR, Nichols PD \& Carter CG (2007) Replacement of fish oil with thraustochytrid Schizochytrium sp L oil in Atlantic salmon parr (Salmo salar L) diets. Comp Biochem Physiol A Mol Integr Physiol 148, 382-392.

65. Schwartz MW, Woods SC, Porte D Jr, et al. (2000) Central nervous system control of food intake. Nature 404, 661-671.

66. Murashita K, Jordal A-EO, Nilsen TO, et al. (2011) Leptin reduces Atlantic salmon growth through the central pro-opiomelanocortin pathway. Comp Biochem Physiol A Mol Integr Physiol 158, 79-86.

67. Sissener NH, Hemre G-I, Espe M, et al. (2013) Effects of plantbased diets on glucose and amino acid metabolism, leptin, ghrelin and GH-IGF system regulation in Atlantic salmon (Salmo salar L.). Aquac Nutr 19, 399-412.

68. Ng WK, Sigholt T \& Rell JG (2004) The influence of environmental temperature on the apparent nutrient and fatty acid digestibility in Atlantic salmon (Salmon salar L.) fed finishing diets containing different blends of fish oil, rapeseed oil and palm oil. Aquac Res 35, 1228-1237.

69. Menoyo D, Lopez-Bote CJ, Diez AS, et al. (2007) Impact of $n-3$ fatty acid chain length and $n-3 / n-6$ ratio in Atlantic salmon (Salmo salar) diets. Aquaculture 267, 248-259.

70. Bracco U (1994) Effect of triglyceride structure on fat absorption. Am J Clin Nutr 60, 1002-1009.

71. Rombout JH, Abelli L, Picchietti S, et al. (2011) Teleost intestinal immunoology. Fish Shellfish Immunol 31, 616-626.

72. Niklasson L, Sundh H, Fridell F, et al. (2011) Disturbance of the intestinal mucosal immune system of farmed Atlantic salmon (Salmo salar), in response to long-term hypoxic conditions. Fish Shellfish Immunol 31, 1072-1080.

73. Cieza RJ, Cao AT, Cong Y, et al. (2012) Immunomodulation for gastrointestinal infections. Expert Rev Anti Infect Ther 10, 391-400.

74. Schreiber O, Petersson J, Walden T, et al. (2013) iNOS-dependent increase in colonic mucus thickness in DSS-colitic rats. PLOS ONE 8, e71843.

75. Xu H, Dong X, Ai Q, et al. (2014) Regulation of tissue LC-PUFA contents, $\Delta 6$ fatty acyl desaturase (FADS2) gene expression and the methylation of the putative FADS2 gene promoter by different dietary fatty acid profiles in Japanese seabass (Lateolabrx japonicus). PLOS ONE 9, e87726.

76. Tocher DR (2003) Metabolism and functions of lipids and fatty acids in teleost fish. Rev Fish Sci 11, 107-184.

77. Mørkøre T \& Rørvik K-A (2001) Seasonal variations in growth, feed utilisation and product quality of farmed Atlantic salmon (Salmo salar) transferred to seawater as $0+$ smolts or $1+$ smolts. Aquaculture 199, 145-157.

78. Cerezuela R, Guardiola FA, Meseguer J, et al. (2012) Enrichment of gilthead seabream (Sparus aurata L.) diet with microalgae: effects on the immune system. Fish Physiol Biochem 36, 1729-1739. 